NBER WORKING PAPER SERIES

\title{
MANAGING HOUSEHOLDS' EXPECTATIONS WITH UNCONVENTIONAL POLICIES
}

\author{
Francesco D'Acunto \\ Daniel Hoang \\ Michael Weber \\ Working Paper 27399 \\ http://www.nber.org/papers/w27399 \\ NATIONAL BUREAU OF ECONOMIC RESEARCH \\ 1050 Massachusetts Avenue \\ Cambridge, MA 02138 \\ June 2020
}

Parts of the results in this paper have previously circulated under the title "The Effect of Unconventional Fiscal Policy on Consumption Expenditure." This research was conducted with restricted access to Gesellschaft für Konsumforschung (GfK) data. The views expressed here are those of the authors and do not necessarily reflect the views of GfK. We thank the project coordinator at GfK, Rolf Buerkl, for help with the data and insightful comments. We also thank Sumit Agarwal, Rudi Bachmann, Oli Coibion, Giancarlo Corsetti, Andreas Fuster, Dimitris Georgarakos, Yuriy Gorodnichenko, Refet Guerkaynak, Luigi Guiso, Valerie Ramey, Tarun Ramodarai, Chris Roth, Eric Sims, Andrea Tambalotti, Giorgio Topa, Nathanael Vellekoop, Mirko Wiederholt, Johannes Wohlfart, Basit Zafar, and seminar and conference participants at various institutions. Weber gratefully acknowledges financial support from the University of Chicago, the Fama Research Fund, and the Fama-Miller Center. The views expressed herein are those of the authors and do not necessarily reflect the views of the National Bureau of Economic Research.

NBER working papers are circulated for discussion and comment purposes. They have not been peer-reviewed or been subject to the review by the NBER Board of Directors that accompanies official NBER publications.

(C) 2020 by Francesco D'Acunto, Daniel Hoang, and Michael Weber. All rights reserved. Short sections of text, not to exceed two paragraphs, may be quoted without explicit permission provided that full credit, including $\left({ }^{\circ}\right.$ notice, is given to the source. 
Managing Households' Expectations with Unconventional Policies

Francesco D’Acunto, Daniel Hoang, and Michael Weber

NBER Working Paper No. 27399

June 2020

JEL No. D12,D84,D91,E21,E31,E52,E65

\section{ABSTRACT}

With a binding effective lower bound on interest rates and large government deficits, conventional policies are unviable and policymakers resort to unconventional policies, which target households' expectations directly. Using unique micro data and a difference-in-differences strategy, we assess the effectiveness of unconventional fiscal policy and forward guidance, both of which aim to stimulate consumption via raising households' inflation expectations. All households' inflation expectations and spending plans react to unconventional fiscal policy. Instead, households, contrary to experts, do not react to forward guidance. We argue that policies aiming to affect households directly are ineffective if (non-expert) households do not understand them.

\author{
Francesco D'Acunto \\ Boston College \\ Carroll School of Management \\ dacuntof@bc.edu \\ Daniel Hoang \\ Karlsruhe Institute of Technology \\ Kaiserstr. 12 \\ 76128 Karlsruhe \\ Germany \\ daniel.hoang@kit.edu
}

\author{
Michael Weber \\ Booth School of Business \\ University of Chicago \\ 5807 South Woodlawn Avenue \\ Chicago, IL 60637 \\ and NBER \\ michael.weber@chicagobooth.edu
}


"[...] inflation will start rising and the usual pattern of central bank reaction would dictate a resolute firming of the stance. Its promise not to follow that usual pattern of reaction will be painful to fulfill, when that time comes, because the central bank will have to watch inflation rising while remaining atypically passive. But that promise has a value today, as it generates optimistic expectations, supports spending and thus facilitates the central bank's job at present."

Peter Praet (2013): Forward guidance and the ECB.

"This [VAT] tax-induced inflation would give households an incentive to spend sooner rather than waiting until prices are substantially higher."

Martin Feldstein (2002): Discretionary fiscal policy in a low interest rate environment.

Stimulating households' consumption is one of the most powerful transmission channels of fiscal and monetary policies, because consumption is the largest component of GDP (Agarwal and Qian (2014); Beraja, Fuster, Hurst, and Vavra (2019)). Conventional monetary policy often works through a refinancing channel lowering households' monthly mortgage payments and increasing disposable income (Agarwal et al. (2019); Abel and Fuster (2019)). But even when central banks can still lower nominal policy rates, this refinancing channel can be clogged up because many households do not actively refinance and banks fail to renegotiate (Andersen, Campbell, Nielsen, and Ramadorai (2020); Adelino, Gerardi, and Willen (2013)). When nominal interest rates fall below the reversal rate, inflated central-bank balance sheets limit the scope of quantitative easing (Di Maggio, Kermani, and Palmer (2020)), and high debt-to-GDP ratios limit the fiscal space, stimulating consumption requires policies that manage households' expectations directly and not through financial intermediaries and firms (Roth and Wohlfart (2019); Agarwal et al. (2020)).

Macroeconomists have recently proposed two such policies - unconventional fiscal policy (Correia et al. (2013)) and forward guidance (Eggertsson and Woodford (2003)). Theoretically and in the eyes of policy-makers, both policies should stimulate aggregate demand through raising households' inflation expectations, which, based on the consumer Euler equation, should reduce incentives to save. The empirical effectiveness of forward guidance, though, is highly debated (e.g., see Del Negro et al. (2015)), and the empirical effectiveness of unconventional fiscal policy has been barely discussed in the literature (see D'Acunto, Hoang, and Weber (2018)).

In this paper, we investigate the conditions under which policymakers can successfully manage households' inflation expectations and thus influence their consumption, saving, and borrowing decisions directly without the need of transmission through financial intermediaries. We compare the effectiveness of unconventional fiscal policy - the pre-announcement of higher 
future consumption taxes - to forward guidance - the explicit guidance by central banks about the future path of monetary policy rates. Unconventional fiscal policy trivially communicates to households higher future prices for consumption goods, which makes the intertemporal substitution channel the Euler equation predicts vivid and easy to grasp. Forward guidance, instead, can only be effective if households understand that keeping policy rates low for longer than a conventional policy function prescribes will generate future inflation, and hence that spending should be front loaded. Both policies should generate higher inflation expectations and hence higher immediate spending, but the extent to which non-expert households grasp these predictions likely differs across unconventional policies. ${ }^{1}$

Figure 1: Inflation Expectations \& Durable Purchases
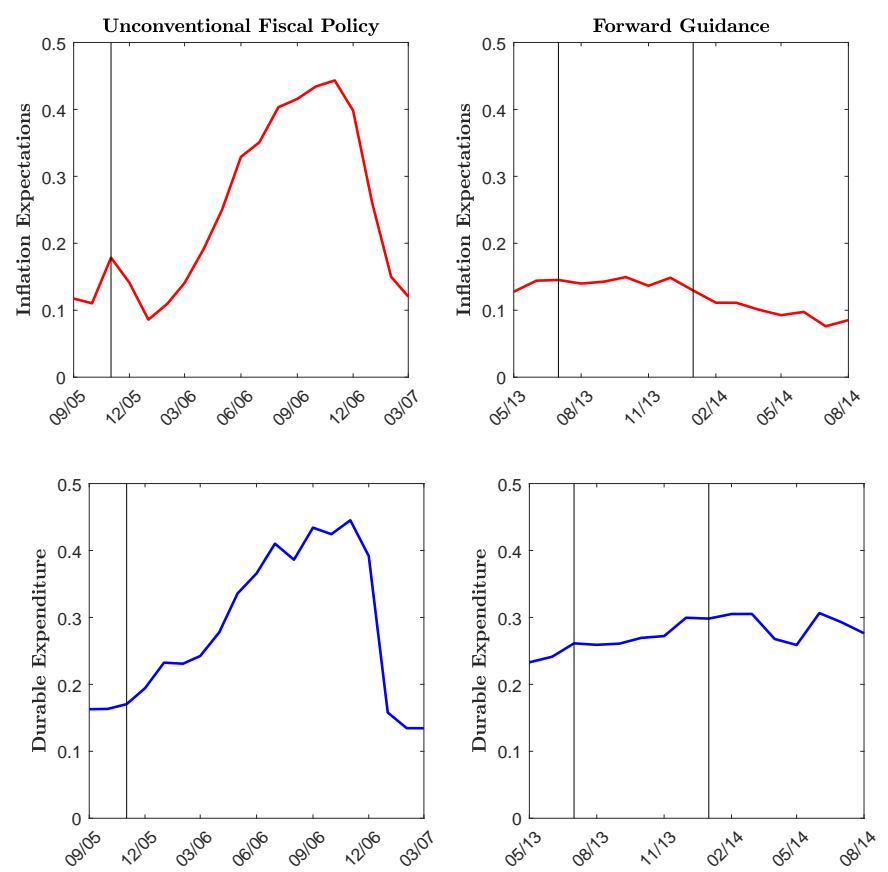

This figure plots the share of German consumers that expect higher inflation in the next 12 months compared to the previous 12 months in the top panels and the share of German consumers that think it is a good time to purchase larger ticket items in the bottom panels. We use the confidential micro data underlying the GfK Consumer Climate MAXX survey to construct these variables. In the left panels, the vertical line signals the unconventional fiscal policy announcement (November 2005). In the right panels, the two vertical lines signal the forward-guidance announcements by the president of the European Central Bank, Mario Draghi (July 2013 and January 2014).

To compare the effects of unconventional fiscal policy and forward guidance empirically, we use unique individual-level data on a large representative population across several European

\footnotetext{
${ }^{1}$ Policymakers discuss explicitly the direct transmission channel of forward guidance through households' expectations. For instance, Benoit Coeure, former member of the Executive Board of the ECB, described the expected effects of forward guidance announcements as follows: "[T] he benefits of higher inflation expectations (are) in terms of front-loaded spending."
} 
countries and propose a difference-in-differences design. Figure 1 plots the average inflation expectations (top panels) and propensity to purchase durable goods (bottom panels) based on the raw household-level data around an unconventional fiscal policy announcement (left panels) and two forward guidance announcements (right panels). ${ }^{2}$

Although theoretically both policies should raise households' inflation expectations and spending on impact, only unconventional fiscal policy announcements produce these outcomes in the raw data. Forward guidance announcements do not appear to manage expectations or spending plans. ${ }^{3}$ As we show below, they do not reduce the cross-sectional dispersion of inflation expectations either, although theory predicts this reduction, because households receive a common signal about future inflation (Coibion et al. (2019)). ${ }^{4}$

To the best of our knowledge, no fiscal authorities around the world have yet implemented measures of unconventional fiscal policy in times of low interest rates. Generic consumption-tax changes do not qualify (D'Acunto et al. (2018)). First, the policy announcement should be unexpected. Moreover, the announcement should happen well before the implementation of the tax increase, so that households have the time to re-optimize their medium- and long-run consumption and saving plans. Also, the announcement should not trigger a change in nominal interest rates, so that higher inflation expectations result in lower real interest rates, reduce households' saving motives, and increase their consumption via intertemporal substitution.

Although it was not originally labeled as unconventional fiscal policy, we consider the unexpected announcement of a VAT increase in Germany in November 2005, to be implemented in January 2007. Two features make this pre-announcement uniquely suited. First, the European Union (EU) largely imposed this policy on the German administration to avoid an infringement procedure for the breach of the Maastricht Treaty, which imposes an arbitrary cap of government deficit to gross GDP of $3 \%{ }^{5}$ The VAT-increase announcement was unexpected and due to inherited fiscal deficits (Romer and Romer (2010) and Alesina, Favero, and Giavazzi (2015)). ${ }^{6}$ Second, Germany has no monetary sovereignty as a member of the European Monetary Union (EMU). The ECB explicitly excluded any increase in nominal interest rates to counteract the

\footnotetext{
${ }^{2}$ We discuss the policy announcements in detail below.

${ }^{3}$ Households do not even react to forward guidance with a delay: No indirect effects arise through financial markets reducing long-term rates and households increase their propensity to take out debt and increase spending.

${ }^{4}$ Unfortunately, we do not observe the full distribution of inflation expectations within individual respondents in our data.

${ }^{5} \mathrm{~A}$ recent debate suggests that the $3 \%$ threshold was chosen by bureaucrats without any specific motivation. See, e.g., https://www.faz.net/aktuell/wirtschaft/wirtschaftswissen/3-prozent-defizitgrenze-wie-das-maastrichtkriterium-im-louvre-entstand-12591473.html.

${ }^{6}$ In appendix section A.2 we discuss this point and the institutional setting in detail.
} 
price pressure from a higher VAT in Germany. ${ }^{7}$

The German setting is viable to our comparative analysis, because the same population also faced two forward-guidance announcements by former ECB President Mario Draghi. Draghi announced the introduction of forward guidance as a policy tool in the Euro Area on July 4 2013 and "firmly reiterate(d)" it on January $92014 .^{8}$

The raw-data time-series evidence in Figure 1 is vivid, but hinders us from any conclusions about whether any of the two policies has successfully managed households' expectations: Any unobserved shocks contemporaneous to the announcements could explain the dynamics of expectations and spending plans.

To tackle this identification challenge, we propose an identification strategy in the spirit of Poterba (1996). We consider consumers in other EU countries not exposed directly to the German VAT shock and/or to the ECB measures of forward guidance as counterfactual for the behavior of Germans had the policy announcements not happened.

Our micro data allow matching German and foreign consumers based on demographics, which is important because different demographics react differently to changes in inflation expectations (Bachmann et al. (2015)). Moreover, in our data we observe directly a set of determinants of spending plans that are often unobserved in administrative data, such as households' income expectations, financial outlook, employment status, and housing choices.

We match German and foreign consumers based on observables and propose a differencein-differences empirical strategy. Because we have access to micro data from the harmonized European Commission (EC) consumer survey program for Germany, France, the UK, ${ }^{9}$ and Sweden, for the forward guidance announcements, we use counterfactual households in the UK and Sweden who were not exposed directly to these announcements because their countries did not belong to the Euro Area. For unconventional fiscal policy, we consider French households as counterfactual, who were subject to the same nominal interest rates as Germans.

German and foreign consumers are likely to differ along several dimensions. Our identification design allows us to absorb systematic time-invariant differences between Germany and other countries, such as differences in legal systems and cultural attitudes. Moreover, we lever the demographic information in our micro data to focus on matched German and foreign

\footnotetext{
${ }^{7}$ Then ECB board member Axel Weber stated that "We know what the effects of the VAT increase are; as is the case for oil prices, we do not consider one-off effects" (Weber (2006)). See appendix section A.3 for a detailed discussion.

8 "The Governing Council has taken the unprecedented step of giving forward guidance in a rather more specific way than it ever has done in the past. In my statement, I said "The Governing Council expects the key ..." - i.e. all interest rates - "... ECB interest rates to remain at present or lower levels for an extended period of time." It is the first time that the Governing Council has said something like this." See: "Introductory statement to the press conference (with Q\&A)" available at https://www.ecb.europa.eu/press/pressconf/2013/html/is130704.en.html.

${ }^{9}$ For the periods we study, the UK was part of the EU.
} 
consumer pairs based on a large set of characteristics, such as age, income, and education. Systematic and time-varying differences in the demographic composition of German and foreign consumers thus cannot drive our results.

The main concern with our strategy is the possibility that unobserved time-varying country-level shocks concurrent to the policy announcements explain the systematic differences in expectations across countries over time. The main assumption our strategy requires is that inflation expectations and spending plans would have followed the same trend as those of foreigners had the announcements not happened. Although this assumption is untestable, we can compare the average expectations of Germans and foreigners around the policy announcements, and we can test the null hypothesis that foreign consumers' expectations did not change around the shock. We find that the expectations and spending plans of non-Germans did not change around the announcements. Moreover, we cannot reject either economically or statistically that Germans' and foreigners' expectations and spending plans followed parallel trends before the announcements. In terms of internal validity, we also show that Germans' inflation expectations and other economic expectations, such as income expectations, followed parallel trends before the announcements.

Using our difference-in-differences strategy, we confirm the results in Figure 1. The unconventional fiscal policy announcement resulted in a large increase in German households' willingness to purchase durable goods throughout 2006, the period after the announcement and before the increase. A back-of-the-envelope calculation suggests the announcement resulted in $10.3 \%$ higher real durable consumption growth throughout 2006. The forward-guidance announcements, instead, had no detectable effects on expectations or readiness to spend on durables.

Whereas both forms of unconventional policy should operate through the consumer Euler equation, households' reactions might differ for several reasons. For instance, households might find forward guidance announcements not credible because this policy is not time consistent, whereas unconventional fiscal policy can be time consistent. Yet, Andrade and Ferroni (2019) show that both the stock market and inflation swap rates reacted positively to the forward guidance announcements; moreover, professional forecasters updated their GDP outlook and inflation expectations upward subsequent to the announcement. These reactions constitute evidence that experts found the forward guidance announcements we study time consistent and credible. The results also directly rule out that market participants and professional forecasters interpreted the announcements as a signal of worse future economic conditions, so-called Delphic forward guidance (Campbell et al. (2012)). Andrade and Ferroni (2019) instead conclude that "Odyssean shocks became predominant over the post-2012 period during which policy rates 
went to zero" and argue that the announcements we study in this paper resulted in some of the largest market-based shocks during the sample they study. ${ }^{10}$

Reaction to these two policies might also differ based on households' sophistication in economic matters: The implications of unconventional fiscal policy for future price changes are trivial-prices will increase at a specified date in the future-whereas grasping the implications of forward guidance for future price changes requires sophistication in economic matters. This interpretation is consistent with earlier evidence that the accuracy of households' expectations and their understanding of conventional measures of fiscal and monetary policy varies systematically with households' sophistication. ${ }^{11}$

Consistent with earlier research, ${ }^{12}$ the unconditional association between inflation expectations and consumption plans is higher for sophisticated consumers. At the same time, all consumers in our sample reacted similarly to the VAT announcement irrespective of their sophistication, which corroborates the conjecture that households do not need a high level of sophistication to understand the implications of unconventional fiscal policy.

To further corroborate this heterogeneity test, we also consider a dimension under which households should react differently, irrespective of their sophistication - the likelihood of binding financial constraints. Even if all households understood the implications of unconventional fiscal policy, households with less resources to spend on impact should display a muted reaction. And, indeed, Germans who were more likely to face financial or liquidity constraints increased their spending by about $25 \%$ less than unconstrained Germans around the unconventional fiscal policy announcements. ${ }^{13}$ The muted response for constrained households also alleviates concerns that any other concurrent shock drives the homogeneous response by household demographics.

We then move on to consider the same heterogeneity tests for forward guidance announcements. Because financial market participants and professional forecasters reacted to such announcements, one might wonder whether sophisticated households reacted too. We find that the lack of reaction was homogeneous across demographics, both at announcement as well as in the medium run, which suggests that only agents with extremely high levels of sophistication,

\footnotetext{
${ }^{10}$ The literature labels the conventional form of forward guidance that is introduced by Eggertsson and Woodford (2003) as Odyssean because it involves a central bank commitment to keep interest rates low in the future even though the conventional reaction function would predict an increase in rates.

${ }^{11}$ See, e.g., Agarwal et al. (2009); D'Acunto, Malmendier, Ospina, and Weber (2019); D'Acunto, Malmendier, and Weber (2018); D'Acunto, Hoang, Paloviita, and Weber (2020)).

${ }^{12}$ For instance, see Bachmann et al. (2015); Burke and Ozdagli (2014); Armantier, Bruine de Bruin, Topa, Klaauw, and Zafar (2015); Cashin (2016); Ichiue and Nishiguchi (2015); Crump, Eusepi, Tambalotti, and Topa (2015); Vellekoop and Wiederholt (2017); Christelis, Georgarakos, Jappelli, and van Rooij (2016); and the evidence from historical data in Romer and Romer (2013); Eggertsson (2008); Jalil and Rua (2016).

${ }^{13}$ We consider three proxies for financial and liquidity constraints - a qualitative answer about binding financial constraints, income levels, and homeownership, which as we discuss below is a strong proxy for household wealth in Germany.
} 
such as experts, react to forward guidance. Moreover, neither constrained nor unconstrained households reacted, which suggests that a potential lack of resources to spend around the forward guidance announcements which occurred on the height of the European sovereign debt crisis cannot explain the ineffectiveness of forward guidance. Moreover, we also do not detect any delayed reaction on the part of households suggesting that an indirect transmission through financial markets did not occur. For example, forward guidance announcements might reduce long term borrowing rates, increase households' willingness to take out loans which is ultimately reflected in larger durable purchases. Finally, income perceptions and expectations did not react around the forward guidance announcements which makes an indirect transmission of forward guidance through income expectations that is central in modern heterogeneous agent New Keynesian models (HANK) unlikely (Slacalek et al. (2020)).

Taken together, our results show substantial differences in households' reactions to unconventional policies that operate theoretically through the same channels. Unconventional fiscal policy, whose implications for expectations and choice are easy to grasp, triggers similar reactions across sophisticated and unsophisticated households. Instead, households do not react to forward guidance, whose implications are harder to grasp, even though experts found these announcements credible and reacted. These empirical results are consistent with recent theoretical work in macroeconomics suggesting that limited cognitive abilities might help explain the forward guidance puzzle (see, e.g., Farhi and Werning (2018), Gabaix (2016), Woodford (2018), Angeletos and Lian (2017), and Ilut and Valchev (2017)).

Our analysis contains some caveats. The data consist of repeated cross sections of consumers. We cannot exploit within-household variation in inflation expectations to control for time-invariant unobserved heterogeneity at the household level. Also, the survey elicits consumers' willingness to purchase durable goods but we do not observe actual purchases. Kreiner, Lassen, and Leth-Petersen (2013) exploit a setting in which survey-based and administrative data about the same variables are available to assess the accuracy of survey-based answers. For the case of reported expenditure, they find that measures based on surveys exhibit a high correlation with measures based on actual administrative data (see also Coibion et al. (2020a) for evidence in the US). Although our data do not allow implementing the tests in Kreiner, Lassen, and Leth-Petersen (2013), we show that the average survey-based willingness to spend closely tracks the average realized durable consumption expenditure in Germany based on administrative data, which is consistent with evidence in Bachmann, Berg, and Sims (2015) for the US (see Figure A.1 in the online appendix).

Note also that the survey we use elicits only qualitative measures of inflation expectations. Using our qualitative measure, we show in Figure A.2 in the online appendix that households' 
inflation expectations track closely lagged actual realized inflation - the measure captures meaningful variation in inflation expectations by households. Instead, research that uses quantitative measures of expectations finds an upward bias in average inflation expectations relative to ex-post realized inflation, and substantial dispersion of the levels of inflation expectations across households (Armantier et al. (2015), D'Acunto et al. (2018)). This discrepancy is consistent with households having correct directional expectations regarding inflation - which we capture with our qualitative measure - but incorrect perceptions regarding the level of inflation (see Vellekoop and Wiederholt (2017)). We discuss these points in more detail in section I.

\section{A. Related Literature}

Our paper builds on the recent revival of research on households' subjective expectations. Bernanke (2007) motivates this agenda arguing inflation expectations drive consumers' consumption, saving, and borrowing decisions, workers' wage bargaining with firms as well as managers' price-setting decisions, and the effectiveness of fiscal and monetary policy, among other outcomes. Malmendier and Nagel (2009) find lifetime experiences matter for inflation expectations and mortgage choices, Kuchler and Zafar (2018) show individuals extrapolate from their experiences to aggregate house price expectations, D'Acunto et al. (2019) and Cavallo et al. (2017) show individuals extrapolate from their shopping bundles to aggregate inflation and D'Acunto et al. (2019a,b, 2020) find large heterogeneity in the forecast accuracy for inflation and in the reaction of agents' choices to changes in interest rates and inflation expectations by cognitive abilities. We depart from this literature by not focusing on the description of which features explain households' expectations but on how policy makers might manage household expectations directly and target households, instead of financial institutions, as agents of transmission of fiscal and monetary policy.

On the methodological side, our paper belongs to a growing strand of the empirical macrofinance literature that uses micro data to obtain causal identification either through natural experiments (Fuchs-Schuendeln and Hassan (2016); Bailey, Dávila, Kuchler, and Stroebel (2019); D'Acunto, Prokopczuk, and Weber (2018); D'Acunto (2014)) or through information treatments in controlled environments (Coibion, Gorodnichenko, and Weber (2019); D'Acunto (2018); Roth and Wohlfart (2019); Andre, Pizzinelli, Roth, and Wohlfart (2019); Coibion, Gorodnichenko, and Weber (2020b); Coibion et al. (2020)). We contribute to this area by proposing a differencein-differences strategy based on unexpected policy announcements, paired with household-level matching, to allow comparison of the expectations and plans of observationally indistinguishable households. 


\section{Data}

\section{A. Data Sources}

We use the confidential micro data underlying the GfK Consumer Climate MAXX survey. GfK conducts the survey on behalf of the Directorate General for Economic and Financial Affairs (DG ECFIN) of the European Commission. We use similar data from the harmonized surveys of DG ECFIN for several other European countries. ${ }^{14}$ GfK asks a representative repeated cross section of 2,000 German households questions about general and personal economic conditions, inflation expectations, and willingness to spend on consumption goods at the monthly frequency. We obtained access to the micro data for the period starting in January 2000 and ending in February 2016. The online appendix contains the original survey and a translation to English.

We use the answers to the following two questions in the survey to construct the main variables in our baseline analysis:

Question 8 Given the current economic situation, do you think it's a good time to buy larger items such as furniture, electronic items, etc.?

Households could answer, "It's neither a good nor a bad time," "No, it's a bad time," or "Yes, it's a good time."

Question 3 How will consumer prices evolve during the next twelve months compared to the previous twelve months?

Households could answer, "Prices will increase more," "Prices will increase by the same," "Prices will increase less," "Prices will stay the same," or "Prices will decrease." We create a dummy variable that equals 1 when households answered, "Prices will increase more," to get a measure of higher expected inflation.

We also use questions regarding expectations about general economic variables, personal income or unemployment, and a rich set of socio-demographics.

\section{B. Descriptive Statistics}

Table 1 contains descriptive statistics. On average, $22 \%$ of individuals said it was a good time to buy durables, $22 \%$ said it was a bad time, and the others are indifferent. Thirteen percent of individuals expected higher inflation in the following 12 months. More than $80 \%$ of respondents thought prices in the previous 12 months increased substantially, somewhat, or slightly, with equal proportions for each answer. Only $15 \%$ thought prices remained the same, and essentially nobody thought prices decreased.

\footnotetext{
${ }^{14}$ We discuss the data for other European countries in more detail in the online appendix.
} 
The sample is roughly balanced between women and men. Most respondents completed high school, but had no college education. ${ }^{15}$ The mean household's size was 2.5 , and the majority of households lived in cities with fewer than 50,000 inhabitants.

Panel C of Table 1 reports statistics for individuals' personal expectations. Most individuals thought their financial situation had not changed in the previous 12 months, and they expected the same for the future. Moreover, most individuals barely saved, and expected a constant or slightly increasing unemployment rate.

\section{B.1 Inflation Expectations and Actual Inflation}

In quantitative surveys, respondents often report extreme levels of expected inflation. For instance, in the Michigan Survey of Consumers (MSC), $3 \%$ of households expect deflation of up to $50 \%$, and $17 \%$ expect an increase in inflation by more than $9 \%$ per year. A recent literature also discusses an effect of questions' wording on answers (see Armantier et al. (2013)). Assessing whether our qualitative elicitation of inflation expectations captures meaningful variation in ex-post realized inflation rates is thus crucial to corroborate the validity of our data. Appendix figure A.2 shows that our average survey answers are highly correlated with subsequent realized inflation, which is prima facie evidence that our measures of inflation expectations capture meaningful variation in subsequent realized inflation.

In fact, our qualitative measures might be more appropriate than quantitative measures in our repeated cross sections setting. Consider the following example of two households, A and B. Household A perceives an existing inflation rate of $2 \%$. Household B perceives a $20 \%$ inflation rate. Now, suppose that household A expects inflation to increase from $2 \%$ to $3 \%$, and hence thinks it is a good time to purchase durables. Household B instead expects inflation to decrease from $20 \%$ to $15 \%$, and hence wants to postpone durable purchases. If we ran a cross-sectional regression of the reported willingness to purchase durable goods on quantitative inflation expectations, and we could not observe within-household inflation expectations over time, we would estimate a negative relationship between inflation expectations and spending, even though the true underlying relationship is positive. ${ }^{16}$ Our qualitative measures avoid this problem.

Moreover, one might wonder whether retailers increased prices before the VAT increase was implemented, which is what New Keynesian models with monopolistic competition

\footnotetext{
${ }^{15}$ Most respondents completed either Hauptschule or Realschule, and only $8 \%$ of respondents had a college degree.

${ }^{16}$ The example is motivated by Vellekoop and Wiederholt (2017) who find large dispersion in individual level inflation expectations but also find that individual fixed effects capture most of the variation in the panel.
} 
and price-adjustment frictions would predict (Gorodnichenko and Weber (2016)). ${ }^{17}$ In this case, realized inflation might have increased in Germany well before the VAT increase was implemented in January 2007. In Appendix Figure A.3, though, we show that inflation did not increase throughout 2006 and only started to increase in the first half of 2007, and not immediately at implementation in January 2007. One reason for this delayed pass through might be the concern of customer antogonization (Anderson and Simester (2010)). In fact, anecdotal evidence suggests that retailers delayed price increases because they feared a stark drop in demand. ${ }^{18}$ For instance, Media Markt and Saturn, two of the largest German retail chains for consumer electronics, advertised extensively their plans to help prospective customers by lowering prices by $19 \%$, instead of increasing prices by the higher VAT amount. By early 2008, all the categories underlying the German CPI had fully adjusted their prices. ${ }^{19}$ We discuss these institutional details in more detail in online appendix section A.2.

\section{Empirical Strategy}

We move on to discuss the institutional setting of the policy announcements and our empirical strategy.

\section{A. Institutional Setting 1: Unconventional Fiscal Policy}

The ideal experiment to test for the effects of unconventional fiscal policy on households' readiness to spend would require an unexpected pre-announced increase in future consumption taxes that is not counterbalanced by an increase in nominal interest rates.

We isolated one such policy announcement in Germany. In November 2005, the newly formed government unexpectedly announced a 3-percentage-point increase in the VAT, effective in January 2007. The narrative record, which we discuss in detail in the online appendix, suggests the increase was legislated to comply with EU law. In each year between 2001 and 2004, Germany posted a deficit-to-GDP ratio above 3\%. In 2003, the EU opened a procedure against Germany for infringement of the $3 \%$ deficit-to-GDP rule in the Maastricht Treaty. The German government proposed plans to reduce the ratio to $2.9 \%$ in 2005 , but these plans were not followed and the deficit-to-GDP ratio was forecasted to be $3.3 \%$ at the end of 2005 . In November 2005, the EU announced it would fine Germany if immediate actions were not taken to reduce the ratio. A few days later, the newly established right-left coalition announced a

\footnotetext{
${ }^{17}$ We thank Tarun Ramadorai for suggesting this point.

${ }^{18}$ See: $\quad$ http://www.handelsblatt.com/politik/deutschland/staatsdefizit-unter-drei-prozent-deutschesdefizitverfahren-wird-eingestellt/2754740.html.

${ }^{19}$ See: https://www.destatis.de/DE/Publikationen/WirtschaftStatistik/Preise/MwSterhoehungJan2007.pdf.
} 
3-percentage-point increase in VAT, from $16 \%$ to $19 \%$, to be implemented after 14 months, in January 2007. Based on the taxonomy of Romer and Romer (2010), this increase was due to an "inherited budget deficit," and it is indeed classified as such in Alesina et al. (2019).

For our purposes, the fundamental feature of this policy announcement is that Germany has had no monetary sovereignty since joining the EMU. The ECB did not tighten monetary policy to counteract the increase in inflation expectations in Germany, as we document in the online appendix with explicit quotes of former ECB President, Jean-Claude Trichet, and other members of the ECB Governing Council. For this reason, under a Fisher equation logic, a change in consumers' inflation expectations should have translated one-to-one into a change in perceived interest rates, and hence should have decreased the propensity to save and increased spending on impact based on the consumer Euler equation.

\section{B. Institutional Setting 2: Forward Guidance}

Moving on to forward guidance announcements, we consider the first two announcements by the ECB. During the introductory remarks to the press conference on 4 July 2013, President Mario Draghi used an explicit forward guidance announcement as a policy tool for the first time: "The Governing Council expects the key ECB interest rates to remain at present or lower levels for an extended period of time." 20 On 9 January 2014, Mr. Draghi reinforced the stance in a second forward guidance announcement: "Accordingly, we firmly reiterate our forward guidance that we continue to expect the key ECB interest rates to remain at present or lower levels for an extended period of time." 21

Peter Praet, Member of the Executive Board of the ECB at that time, explained in an article that "longer-term interest rates determine the borrowing conditions that are most relevant for a large component of aggregate spending: first and foremost, durable consumption." He moved on to argue that by committing to a future path of short-term interest rates the ECB would be able to stimulate durable spending. ${ }^{22}$ He also explained that "inflation will start rising and the usual pattern of central bank reaction would dictate a resolute firming of the stance. Its promise not to follow that usual pattern of reaction will be painful to fulfill, when that time comes, because the central bank will have to watch inflation rising while remaining atypically passive. But that promise has a value today, as it generates optimistic expectations, supports spending and thus facilitates the central bank's job at present." Mr. Praet was clear about the ECB's expectation that forward guidance announcements should have led households to move

\footnotetext{
${ }^{20}$ See: https://www.ecb.europa.eu/press/pressconf/2013/html/is130704.en.html.

${ }^{21}$ See: https://www.ecb.europa.eu/press/pressconf/2014/html/is140109.en.html.

${ }^{22}$ See https://voxeu.org/article/forward-guidance-and-ecb.
} 
spending forward due to higher inflation in the future and hence higher inflation expectations on impact.

Time inconsistency, as Mr. Praet also emphasizes in the quote, is a potential concern with this form of forward guidance. Central Banks have incentives to deviate from the policy once the liquidity trap is over to avoid generating inflation. Agents in the economy might realize this credibility problem and might not react to the policy announcement for this reason.

For the announcements we consider, though, Andrade and Ferroni (2019) document that financial markets, inflation swaps, and professional forecasters all reacted on impact, which is direct evidence that they all found the announcements credible. Because experts found these measures credible, the possibility that non-expert consumers did not change their inflation expectations because of lack of credibility is unlikely. ${ }^{23}$

\section{Difference-in-Differences Strategy}

Assessing the effects of the policy announcements on German consumers alone would have no causal implications, because all German households were exposed to the same announcements, and hence any shock contemporary to the announcements could have caused the detected reactions. For identification purposes, we need a group of households not affected by the shock, but who behaved similar to German households before the shock so that they can be a plausible counterfactual for the behavior of Germans absent the shock. To this aim, we propose a difference-in-differences empirical strategy in the spirit of Poterba (1996) and Besley and Rosen (1999).

To implement such a counterfactual, we obtained access to the confidential micro data for the same EU harmonized consumer sentiment survey for three additional countries (France, Sweden, and the UK) through national statistical offices and GfK subsidiaries. We use the households in these three countries to construct our control groups for the counterfactual behavior of German consumers, had they not been exposed to the policy announcements.

Our difference-in-differences approach compares German consumers' readiness to purchase durables with the readiness of matched consumers in other European countries, whose observable characteristics are similar to German consumers, before and after the policy announcements.

\footnotetext{
${ }^{23}$ This form of forward guidance announcement, which publicly commits the ECB to future action, falls under the "Odyssean" category based on the taxonomy of Campbell, Evans, Fisher, and Justiniano (2012). Andrade and Ferroni (2019) argue that "Odyssean shocks became predominant over the post-2012 period during which policy rates went to zero (in July 2012) and the Governing Council started to give explicit guidance on future rates (in July 2013)." Irrespective of whether our forward-guidance announcements were Delphic or Odyssean in nature, theory predicts a higher willingness to purchase durable goods after the announcements in either case. Odyssean announcements should cause higher inflation expectations and higher spending through the Euler equation. Under Delphic announcements, lower long-term rates should stimulate spending directly, independent of inflation expectations.
} 
Because the micro-level cross-sectional estimation allows us to absorb any time-invariant country characteristic through country fixed effects, no systematic differences across German and other European consumers can drive our results.

We estimate the average treatment effect of each policy announcement on consumers' readiness to purchase durables as follows:

$$
\left(\overline{D u r}_{\text {German, post }}-\overline{\operatorname{Dur}}_{\text {German, pre }}\right)-\left(\overline{\text { Dur }}_{\text {foreign, post }}-\overline{D u r}_{\text {foreign, pre }}\right),
$$

where $\overline{D u r}_{\text {German, post }}$ is Germans' average readiness to purchase durable goods after each policy announcement; $\overline{D u r}_{\text {German, pre }}$ is Germans' average readiness to purchase durable goods before each policy announcement; and $\bar{D}_{\text {freign, post }}$ and $\overline{D u r}_{\text {foreign, pre }}$ are the analogous averages for foreign households not exposed to the announcements.

\section{Identifying Assumptions}

The parallel-trends assumption is a necessary condition for identification. In our case, it states that our control group behaved similarly to German households both before and after the shock, had the shock not happened. We cannot test whether the parallel-trends assumption held after the shock, because we miss the counterfactual of no shock in Germany. We therefore test for the presence of differential pre-trends before the shock. In the presence of parallel pre-trends, our identifying assumption is that foreign households behaved like German households would have behaved absent the policy announcements over the same period of time.

Figure 2 and Figure 3 provide graphical evidence that we fail to detect violations of parallel pre-trends. Based on the top left panels of the two figures, the trends in inflation expectations and purchasing propensities are parallel for German and foreign consumers before the announcement of the VAT increase (November 2005). Starting in January 2006, both the German consumers' inflation expectations and willingness to buy durable goods started to increase substantially. At the same time, the trends for foreign consumers did not move compared to the pre-shock period.

When we consider the top right panels of both Figure 2 and Figure 3, we find that even in the case of the forward guidance policy announcements the trends in inflation expectations and purchasing propensities were parallel for German and foreign consumers. Contrary to the VAT announcement, we find no noticeable divergence in inflation expectations and purchasing propensities around the forward guidance announcements.

The bottom panels of Figure 2 and Figure 3 repeat the parallel-trends test on a subset of foreign countries. For the unconventional fiscal policy announcement, we only consider French 
consumers. French consumers were not subject to the increase in German VAT but were facing the same nominal interest rates set by the ECB. The similarity of pre-shock trends is even more pronounced when we only use French households as control group (see bottom left panels of Figure 2 and Figure 3 ).

For the forward guidance announcements, we restrict the control group to consumers from the UK and Sweden (see bottom right panels of Figure 2 and Figure 3), who were not part of the EMU and hence not affected by the ECB forward guidance announcements. Again, we confirm these groups of consumers display parallel trends in the pre-announcement periods in terms of both individual inflation expectations and readiness to purchase durable goods.

We also verify that consumers in all countries display a positive association between inflation expectations and willingness to purchase durable goods, as the consumer Euler equation prescribes. We perform this test in columns (6)-(8) in Table 3. In column (5), we report the corresponding baseline effect for German households, excluding the forward guidance and unconventional fiscal policy periods. Foreign households react to their inflation expectations in a similar fashion as German households, which alleviates concerns about the external validity of our strategy. We discuss in more detail the empirical models we estimate, the association between inflation expectations and consumption propensities, and the heterogeneity across demographic groups in section $\mathrm{V}$.

\section{E. Matching Foreign and German Households}

To account for the heterogeneity in responsiveness to inflation expectations (Jappelli and Pistaferri (2014); see also section V), we match German households with similar foreign households to construct our identification sample. We first match each German household in each month with a household in another country interviewed in the same month displaying similar demographic characteristics. Our samples are repeated cross sections, and hence we perform a second level of matching, which pairs up similar households interviewed before and after the shock separately within the German and the foreign survey waves.

We use a nearest-neighbor algorithm to match households based on propensity scores. ${ }^{24}$ We estimate propensity scores with a logit regression of the treatment indicator on gender, age, education, income, and social status, which are the demographic characteristics that are elicited homogeneously across EU countries by the survey.

The matching exercise is meaningful only if matched German and foreign households lie

\footnotetext{
${ }^{24}$ All the results are virtually identical if we perform the monthly matching using a group of control households for each German household, and we minimize the difference in observables of the German household and the group of foreign households.
} 
in the common support of the distributions of the propensity scores. We verify this condition in Figure 4, which plots the distributions for the treatment group for the VAT period in panel A (red, top half of panel A) and the control group (blue, bottom half of panel A) and for the forward guidance period in panel B.

To assess the performance of the matching procedure, we compare average household characteristics across German and foreign households both before and after matching. Table 2 assesses the balancing of the variables we use in the matching process. Panel A refers to the unconventional fiscal policy period and Panel B to the forward guidance period.

In each panel of Table 2, columns (1)-(3) report the sample average of the variables we use to compute the propensity score in the unmatched samples of German and foreign households. T-statistics for two-sided t-tests for whether the estimated means are equal reject the null at all plausible levels of significance, for both policy events. This result confirms that, without the matching step, German and foreign households differ systematically.

In columns (4)-(6), we report the same statistics for the treated and control observations of the matched samples, which we use in our difference-in-differences analysis. In this case, the differences in the estimated means across groups are economically and statistically negligible, which suggests the matching procedure effectively provides us with two similar groups of German and foreign households.

\section{Policy Announcements, Expectations, and Choice}

In this section, we study the effect of policy announcements on inflation expectations, consumption plan reactions, as well as the heterogeneity of reactions across demographics.

\section{A. The Effects of Unconventional Fiscal Policy}

We first consider the effects of unconventional fiscal policy announcements on consumers' inflation expectations and willingness to purchase durable goods.

Figure 1 in the introduction shows a large increase in the share of individuals who expect higher inflation over the following 12 months. In fact, the share quadruples after the announcement (left panel, vertical line) and stays high for the 13 months until the actual VAT increase implementation in January 2007. After the increase, expectations revert to their pre-announcement level.

We run a set of cross-sectional regressions on the matched sample before and after the VAT announcement to estimate the average treatment effect of the VAT shock in equation (1). We set the reference month to June 2005, and we change the end month $m$ across regressions. All 
the results are similar if we use any other month before the announcement of the VAT increase in November 2005.

We estimate the following specification:

$$
\Delta D_{i, 06 / 2005 \rightarrow m}=\alpha+\beta_{m} \times V A T \text { shock }_{i}+\Delta X_{i, 06 / 2005 \rightarrow m}^{\prime} \times \gamma+\epsilon_{i},
$$

where $\Delta D$ ur $_{i, 06 / 2005 \rightarrow m}$ is the difference in the willingness to spend on durable goods between month $m$ and June 2005, VATshock $k_{i}$ is an indicator equal to 1 if the household was exposed to the VAT shock, $\beta_{m}$ captures the effect of the VAT shock on household $i$ 's willingness to buy durables in month $m$, and $\Delta X_{i, 06 / 2005 \rightarrow m}^{\prime}$ is the difference in a set of observables between month $m$ and the baseline month. The observables include the matching variables we use to construct household pairs, as well as income expectations. The results are virtually identical if we change the set of observables, or we exclude them altogether.

The left panel of Figure 5 plots the estimated coefficient $\hat{\beta}_{m}$ (solid line) of equation (2) for each month $m$ from July 2005 to December 2007, as well as the $95 \%$ confidence intervals (dashed line). We find no differences in the readiness to spend on durable goods between German and matched households before the announcement of the VAT increase. Starting in December 2005, German households' willingness to spend increased relative to matched households: German households were 3.8 percentage points (s.e. 1.5 percentage points) more likely to declare it was a good time to purchase durable goods after the announcement compared to before, and compared to matched foreign households. The effect increased in magnitude throughout 2006 and peaked at 34 percentage points in November 2006. The average treatment effect dropped to zero in January 2007 once the VAT increased and higher inflation materialized. ${ }^{25}$

The left panel of Figure 5 shows the VAT shock had a strong and positive effect on Germans' willingness to spend, even after controlling for the purchasing propensities of similar households not exposed to the shock in the difference-in-differences setting. The average treatment effect increased over time. This finding is consistent with Crossley et al. (2014), who argue that intertemporal arbitrage should increase over time and be highest right before the tax increase, because of irreversibility, uncertainty, and storage costs.

\section{B. The (Non-)Effects of Forward Guidance}

In the second step, we study whether the two ECB forward-guidance announcement we observe in our sample period affected consumers' willingness to spend on durable goods.

\footnotetext{
${ }^{25}$ Results are virtually identically if we match on income expectations for the next 12 months, in addition to gender, age, education, income, and social status.
} 
The right panel of Figure 5 plots the estimated coefficient $\hat{\beta}_{m}$ (solid line) of equation (2) for each month $m$ from April 2013 to June 2014, as well as the 95\% confidence intervals (dashed line). We find no difference in the readiness to spend on durable goods between German and matched households before the first forward guidance announcement in July 2013. Germans' propensity to spend did not change after the first forward guidance announcement relative to before and relative to matched foreign households. Even around the second announcement in January 2014, the announcement has no effect on the willingness to spend.

The propensity to spend did not move well after the second announcement either, and hence forward guidance announcements not only had no effect on impact, but did not have any delayed indirect effects through financial intermediaries, such as due to an effect of lower long-term interest rates on credit-financed consumption.

\section{Dispersion of Inflation Expectations}

Our baseline analysis focuses on the first moment of inflation expectations, but the policy announcements might also imply an indirect effect on the second moment of expectations and reduce the dispersion of expectations across individuals. ${ }^{26}$ Indeed, Coibion et al. (2019) show if priors are symmetrically distributed around the signal, the average expectations of a pool of Bayesian agents would not change after a shock. Rather, expectations uncertainty might change if agents update their beliefs. This seems plausible especially for the forward guidance announcements, which do not provide a quantitative level for future inflation but give all agents a clear common signal about the direction of the increase. In Coibion et al. (2019), providing common signals such as information treatments about macroeconomic variables reduces the dispersion of expectations.

Unfortunately, our survey does not include direct elicitation of the full distribution of individual beliefs about inflation, and hence we cannot measure the second moment of inflation expectations at the individual level. We can still assess, though, a potential effect of the two unconventional policies on the cross-sectional dispersion of expectations in the population.

In Figure 10, we plot the average monthly coefficient of variation of inflation expectations around the unconventional policy announcements. We compute the coefficient of variation as the ratio between the monthly cross sectional standard deviation and the monthly average inflation expectations in the German sample. ${ }^{27}$

The left panel of Figure 10 refers to unconventional fiscal policy. We detect a notable drop

\footnotetext{
${ }^{26}$ We thank Tarun Ramadorai for suggesting this point.

${ }^{27}$ We scale the standard deviation by the average inflation expectations because the standard deviation increases mechanically when average inflation expectations increase.
} 
in the coefficient of variation starting in January 2006 through the end of 2006. Although the normalization by average inflation expectations drives, at least in part, this drop, because we know from above that average inflation expectations increase over this period, the evidence is at least inconsistent with a substantial increase in the cross-sectional variation of inflation expectations during the period between policy announcement and implementation of the VAT increase.

The right panel of Figure 10 considers the two forward guidance announcements. Similar to the first moment, we fail to detect a drop in the dispersion of expectations around these announcements.

\section{Who Reacts to the Unconventional Policies?}

Earlier research has identified several individual-level characteristics that are relevant for households' understanding and reaction to economic policies. Examples of such characteristics include cognitive abilities - low-IQ men are less responsive to economic policies than high-IQ men (D'Acunto, Hoang, Paloviita, and Weber (2019a,b, 2020)); gender-women have systematically higher inflation expectations than men (D'Acunto, Malmendier, and Weber (2018); D'Acunto, Malmendier, Ospina, and Weber (2019)); and socio-economic status-low-status individuals have systematically higher and more uncertain inflation expectations than high-status individuals (Kuhnen and Miu (2017)).

For the case of unconventional fiscal policy, the announcement communicates trivially that consumer prices will increase by a pre-specified amount at a known future date. Consumers should easily understand that delaying their spending until after the price increase will be costly.

Moreover, because this message is easy to convey and explain, the media might cover and discuss it in more detail than other news about economic policy. Not only specialized media, but also mainstream media and tabloids are likely to cover and discuss the implications of this type of announcement. For instance, a few weeks before the VAT increase, the largest German tabloid, Bild-Zeitung, titled: "Achtung, Mehrwertsteuer-Fallen", which translates to "Attention, Value-Added Tax Traps." Anecdotally, the German media discussed the implications of such measure throughout the pre-implementation period. Due to the breadth and persistence of media coverage, all consumers, and not only those consuming specialized media, might have been exposed to the announcement and its implications in several occasions during the 
pre-implementation period. ${ }^{28}$ For all these reasons, we conjecture that unconventional fiscal policy might affect the inflation expectations of every consumer, irrespective of sophistication in economic matters.

To assess our conjecture, we repeat the difference-in-differences analysis after splitting our sample across several demographic characteristics that correlate with sophistication in economic matters and/or systematic differences in inflation expectations and readiness to spend. To perform this test, we perform the matching of German and foreign households each month within each demographic group. We then estimate the average treatment effect of the policy announcement on households' readiness to purchase durable goods separately within each matched demographic group.

Figure 6 plots the estimated average treatment effects of the unconventional fiscal policy announcement when splitting the samples based on five demographic variables. First, we consider education levels - whether the respondent has a college degree (High Education) or not (Low Education). Consistent with our conjecture, we find no noticeable difference in the reactions of respondents with different levels of education after the announcement.

The second characteristic we consider is gender, because, unconditionally, women have systematically higher inflation expectations than men (D'Acunto et al. (2018)). Differences in the reaction across genders throughout 2016 are economically negligible and we cannot reject the null hypothesis that such differences equal zero statistically.

We then split the sample between those expecting higher income over the following 12 months and those expecting the same or lower income over the same period. Different reactions by income expectations would imply an income effect of the announcement. Instead, the reactions are almost identical for households with income expectations of opposite signs.

Moving on to respondents' age, unconditionally - that is, outside the policy periods - we find that older respondents have a lower propensity to spend when they expect higher inflation. This fact is not surprising because older individuals have nominal pensions and lower human capital compared to someone in the labor force. And, yet, we detect no differences in the reaction to the VAT announcement for respondents of different ages.

Finally, we consider socio-economic status. Even in this case, we fail to detect any systematic differences in the reactions of respondents in the lowest and highest socio-economic brackets.

Overall, the homogeneous and universal response to unconventional fiscal policy supports our conjecture that all households appear to understand, be aware, and react to such form of

\footnotetext{
${ }^{28}$ In the online appendix, we report more anecdotal evidence on media captions covering the November 2005 unconventional fiscal policy announcement at the announcement date and throughout 2006.
} 
unconventional policy.

Although consistent with our hypothesis, the striking similarity of reactions across demographics might raise the concern that our analysis captures some mechanical features of the data. ${ }^{29}$ For this reason, we propose an assessment of our conjecture in the spirit of falsification tests. Fortunately, our conjecture of universal reaction irrespective of consumers' sophistication is falsifiable across the domain of financial and liquidity constraints. Intuitively, even though financial and/or liquidity-constrained consumers fully understood the implications of unconventional fiscal policy, their binding constraints would not allow them to bring forward all durable spending before the VAT increase. For this reason, we should observe a muted effect of unconventional fiscal policy on the willingness to spend of constrained households, even if the households understood the policy implications.

In Figure 7, we perform this test using three proxies for the likelihood of binding constraints. The first proxy is a direct question about whether respondents are unable to save any of their income or borrow (high financial constraints) or whether respondents save regularly part of their monthly income (low financial constraints). The second proxy we consider is households' income levels. Intuitively, higher-income households are less likely to face financial constraints relative to low-income households. Third, we consider a split of homeowners and renting households. This split is justified by the fact that, in Germany, homeownership is the strongest predictor of household wealth. ${ }^{30}$

Across all the three proxies for financial/liquidity constraints, the reaction is economically and statistically weaker for more constrained respondents relative to unconstrained respondents.

We then move on to run the heterogeneity analysis across demographics around the two forward guidance announcements. Although we detected no average effect of these announcements on the overall population, sophisticated consumers might react. Unfortunately, we do cannot measure financial literacy and economic sophistication directly in the survey. For instance, we do not know respondents' occupations, which would have allowed us to isolate those working in the financial industry. Nor do we know the major for college-educated respondents, which would have allowed isolating those with a background in economics and finance.

Figure 8 and Figure 9 show the results for the heterogeneity test. Across all demographic splits, we fail to detect any significant reaction to forward guidance announcements. Even college graduates are non-reactive, although, as discussed above, more precise ways to isolate

\footnotetext{
${ }^{29}$ Although we are unable to formulate a compelling reason for why the results might be "mechanical," we fully acknowledge that the consistently overlapping patterns by demographics might appear surprising.

${ }^{30}$ The Bundesbank (2019) shows that the average net worth of German homeowners is Euro $477.8 \mathrm{~K}$ for nonmortgage holders and Euro 336.9K for mortgage holders, whereas it is only Euro $54.7 \mathrm{~K}$ for renters using the micro data from the Panel of Household Finances.
} 
economic literacy might have allowed us to detect a reaction in the small fraction of the German population that has such expertise.

\section{Channels}

In the last part of the paper, we assess a set of potential economic channels through which unconventional fiscal policy announcements might affect consumers' inflation expectations and durable spending plans. Here, we only study unconventional fiscal policy, because we failed to detect any effects of forward guidance announcements.

Unconventional fiscal policy can affect purchasing propensities via an inflation-expectations channel only if consumers' willingness to purchase reacts to changes in their inflation expectations. In times of fixed nominal interest rates, the Euler equation predicts a positive association between consumption and inflation expectations. Earlier research, however, found conflicting evidence about this channel. In this section, we document a positive association between households' inflation expectations and their willingness to purchase durable goods. The size of the association varies substantially across demographics. This result confirms the importance of matching similar households before implementing our difference-in-differences strategy.

\section{A. Intertemporal Substitution}

Consumers' readiness to purchase durable goods derives from discrete, non-ordered choices in a survey. We therefore model the response probabilities in a multinomial-logit setting. ${ }^{31}$

We assume the answer to the question on the readiness to spend is a random variable representing the underlying population. The random variable may take three values, $y \in$ $\{0,1,2\}$ : 0 denotes it is neither a good nor a bad time to purchase durable goods; 1 denotes it is a bad time to purchase durable goods; and 2 denotes it is a good time to purchase durable goods.

We define the response probabilities as $P(y=t \mid X)$, where $t=0,1,2$, and $X$ is an $N \times K$ vector where $N$ is the number of survey participants. The first element of $X$ is a unit vector, and the other $K-1$ columns represent a rich set of household-level observables, including demographics and expectations.

\footnotetext{
${ }^{31}$ Results are similar if we estimate a probit model.
} 
We assume the distribution of the response probabilities is

$$
P(y=t \mid X)=\frac{e^{X \beta_{t}}}{1+\sum_{z=1,2} e^{X \beta_{z}}}
$$

for $t=1,2$, and $\beta_{t}$ is a $K \times 1$ vector of coefficients. The response probability for the case $y=0$ is determined, because the three probabilities must sum to unity. We estimate the model via maximum likelihood to obtain the vector $\beta_{t}$ of coefficients for $t=1,2$, and set the category $y=0$ as the baseline response. We compute the marginal effects of changes in the covariates on the probability that households choose any of three answers in the survey, and report them in the tables.

Table 3 reports the average marginal effects computed from the multinomial logit regressions. We cluster standard errors at the quarter level to allow for correlation of unknown form in residuals across contiguous months. In all columns, we report the marginal effect of the inflation-increase dummy on the likelihood that households respond that it is a good time to buy durables. Columns (1)-(5) focus on the sample of German households, whereas columns (6)-(8) report the results for estimating the same specification separately for households abroad.

In column (1), the inflation-increase dummy is the only explanatory variable. Germans who expect increasing inflation over the following 12 months are on average $5.8 \%$ more likely to answer that it is a good time to buy durables compared to individuals that expected constant or decreasing inflation. Column (2) augments the specification by adding a set of controls, which include perceptions of past inflation (Jonung (1981)), a rich set of demographic characteristics that might determine both purchasing propensities and inflation expectations (see, e.g., Attanasio and Weber (1993)), as well as expectations about personal and macroeconomic variables. The baseline association between expecting higher inflation and readiness to purchase durable goods becomes larger $(8.8 \%)$, which suggests that omitted factors in this analysis are unlikely to dramatically change the results.

In columns (3)-(5) of Table 3, we show the association between inflation expectations and readiness to spend is robust across subperiods. Consistent with our interpretation of the difference-in-differences analysis, the baseline association is larger during the VAT announcement period, and hence unconventional fiscal policy was successful to trigger a higher propensity to purchase durable goods relative to normal times.

A back-of-the-envelope calculation implies the marginal effect of inflation expectations on the willingness to buy durables translates into $4.8 \%$ higher real durable consumption expenditure if all Germans expected higher inflation. During the period after the announcement and before the actual increase in VAT, our back-of-the-envelope calculation implies the increase in VAT by 
3 percentage points resulted in a $10.3 \%$ higher real durable consumption growth. ${ }^{32}$

In columns (6)-(8), we find that the baseline association between inflation expectations and readiness to spend is also true, on average, in each of the countries in our difference-in-differences analysis.

Table 4 studies the variation in the baseline effect by household characteristics. We first consider respondents' education. Columns (1)-(2) of Table 4 report the marginal effects for our baseline specification estimated separately for survey participants with a Hauptschule degree (lowest level of formal education) and those with college education. Households with low levels of education that expect inflation to increase are $6.9 \%$ more likely to have a positive stance toward buying durables compared to households that expected constant or decreasing inflation (column (1)). This marginal effect increases with education, and is more than $50 \%$ larger for household heads that hold a college degree (column (2)).

We find a $5 \%$ higher marginal effect of inflation expectations on the likelihood of richer survey participants with a monthly net income above EUR 2,500 replying that it was a good time to buy durables (column (4)), compared to survey participants with a monthly net income less than EUR 1,000 (column (3)).

Retirees have different time-use and consumption patterns compared to the working-age population, typically have nominal pensions in Germany, hold few real assets, and have lower human capital compared to someone in the labor force. The marginal effect of inflation increases on the willingness to spend is lower for those aged 65 or higher (column (6)) than for the younger population (column (5)).

In our sample, we do not detect large differences in the sensitivity to buy large-ticket items to inflation expectations by gender or income expectations, but high-socioeconomic-status households tend to display a somewhat smaller sensitivity than low-status households (see columns (7)-(12)).

To further assess the intertemporal substitution channel, we ask whether households declare it is a bad time or a good time to save. Higher inflation expectations should trigger a lower willingness to save. Verifying this channel is important, because our results so far might be consistent with households substituting between nondurable and durable spending, without any effects on their propensity to save or overall consumption. Table 5 confirms that higher inflation expectations increase the likelihood German households declare it is a bad time to save and decrease the likelihood they declare it is a good time to save.

\footnotetext{
${ }^{32}$ To reach this suggestive conclusion, we regress the natural logarithm of real durable consumption expenditure at the quarterly frequency on the end-of-quarter value of the average durable purchasing propensity and quarterly dummies, and multiply the resulting coefficient of 0.5396 by the marginal effect of $8.76 \%$ (column (2) of Table 3) and $19.09 \%$ for the period of the natural experiment (see column (3)).
} 
Overall, the results in Table 3 and Table 5 appear consistent with the an intertemporal substitution channel of unconventional fiscal policy.

\section{B. Other Channels}

Unconventional fiscal policy could also affect spending through income and wealth effects rather than intertemporal substitution. For instance, the expected increase in prices might lead households to expect higher income. Figure 11 plots the evolution of average income perceptions and income expectations over the following 12 months together with inflation expectations. The announcement affected average inflation expectations, whereas average income perceptions and income expectations stayed flat throughout the period, and especially around the VAT announcement.

In Figure 12, we find that, around the forward guidance announcements, all expectations stayed flat. Not only inflation expectations did not move, but also income expectations and perceptions were flat, which is direct evidence that exceptionally depressed income expectations during the Great Recession cannot have offset a positive shock of the forward guidance announcement on households' willingness to spend.

Another channel we consider for the unconventional fiscal policy period is intratemporal substitution from non-durable to durable consumption without any increase in overall consumption. Table 5 shows households who expect higher inflation were more likely to report it was a bad time to save relative to households with constant or decreasing inflation expectations. These results make the intratemporal substitution channel unlikely.

A housing-wealth channel and home-equity extraction could also affect households' consumption responses (Leth-Petersen (2010)). In the German context, for instance, this channel might have been triggered by the abolition of German's homeowner subsidy. ${ }^{33}$ First, though, the home-ownership rate is on average below $43 \%$ in Germany, and house-price inflation was largely negative in the 2000s. ${ }^{34}$ Moreover, using data from the German Sample Survey of Income and Expenditure, we find that the homeownership rate was strikingly stable around the policy announcements we study. Specifically, the rate moved from of $43.0 \%$ in 2003 to $43.2 \%$ in 2008 and back to $43.0 \%$ in 2013. A substitution away from home purchases to purchases of other durable goods is therefore unlikely to explain our findings.

Modern heterogeneous-agent models feature a redistribution channel of surprise inflation from lenders to borrowers (see Doepke and Schneider (2006)). Based on the VAT increase of

\footnotetext{
${ }^{33}$ We discuss this and other policy changes that were implemented in the same years as unconventional fiscal policy and forward guidance in more detail in section A.2 of the online appendix

${ }^{34}$ Empirically, we find similar associations between inflation expectations and spending propensities for renters and home owners.
} 
3 percentage points, if all goods are subject to the higher VAT under full tax incidence on the consumer side, we would expect an increase in consumer price inflation of $2.59 \%$. However, the change in inflation is only a surprise for loan contracts that existed before November 2005 and matured after December 2006. For this subset of contracts, we expect a redistribution of nominal wealth from lenders to borrowers after the actual increase in VAT. At the same time, the increase in VAT was permanent and should have resulted in a reduction in wealth corresponding to $2.59 \%$ of lifetime consumption under the assumption that consumers did not change their consumption bundle after the VAT announcement. The total wealth effect of an increase in VAT is therefore most likely negative for both borrowers and lenders, which suggests that our estimates of higher spending after the policy announcement are, if anything, a lower bound of the true effect.

Finally, more elaborate macroeconomic models with financial constraints or hand-to-mouth consumers might also offer alternative channels (Kaplan et al. (2018)). We cannot test for all alternative channels with our data. However, financial constraints or hand-to-mouth consumers are unlikely to drive our findings, because tax increases would result in lower consumption expenditure in these alternative models. In section A.2 in the online appendix we also show that labor-force participation and unit labor costs - additional indirect channels in recent HANK models (Slacalek, Tristani, and Violante (2020)) — did not change during the period we study.

\section{Concluding Remarks}

We assess the effectiveness of expectations-based unconventional policies that have been recently proposed by macroeconomic theory and policymakers - unconventional fiscal policy and forward guidance. Theoretically, these policies should act through the same channels, but we find substantial differences in their empirical effectiveness: in a same representative population, unconventional fiscal policy increased individual inflation expectations and willingness to purchase durable goods, and all demographics reacted similarly to the policy, including less sophisticated consumers. Instead, we do not detect any effects of forward guidance announcements on individual expectations or readiness to spend.

Our results open questions for theoretical and empirical scholars in finance and macroeconomics. For instance, what are the distributional consequences of consumers' lack of reaction to hard-to-grasp policies such as forward guidance? The fact that only financial-market participants and economic experts reacted to forward guidance announcements in the EU opens the possibility to unintended redistributive consequences of policy announcements.

Moreover, the universal reaction to a simple policy like unconventional fiscal policy stresses a 
potentially relevant but overlooked role for the extent to which ordinary households understand the implications of economic policy. For policies that aim to reach households directly, and not through financial intermediaries or firms, policymakers and researchers should consider the simplicity of the policy implications when designing effective policy making. Our results are among the first steps to connect the large body of research on the biases and mistakes of households in the financial domain to the effectiveness of unconventional policies, and macroeconomists and policymakers can learn from applying the body of work in household finance and behavioral finance into policy design. 


\section{References}

Abel, J. and A. Fuster (2019). How do mortgage refinances affect debt, default, and spending? evidence from harp. American Economic Journal: Macroeconomics (forthcoming) (841).

Adelino, M., K. Gerardi, and P. S. Willen (2013). Why don't lenders renegotiate more home mortgages? redefaults, self-cures and securitization. Journal of Monetary Economics 60(7), 835-853.

Agarwal, S., G. Amromin, S. Chomsisengphet, T. Landvoigt, T. Piskorski, A. Seru, and V. W. Yao (2019). Mortgage refinancing, consumer spending, and competition: Evidence from the home affordable refinancing program. Working Paper (15-85).

Agarwal, S., J. C. Driscoll, X. Gabaix, and D. Laibson (2009). The age of reason: Financial decisions over the life cycle and implications for regulation. Brookings Papers on Economic Activity 2009(2), 51-117.

Agarwal, S., Y. Hwee Chua, and C. Song (2020). Inflation expectations of households and the upgrading channel. Working Paper.

Agarwal, S. and W. Qian (2014). Consumption and debt response to unanticipated income shocks: Evidence from a natural experiment in singapore. American Economic Review 104(12), 4205-30.

Alesina, A., C. Favero, and F. Giavazzi (2015). The output effect of fiscal consolidation plans. Journal of International Economics 96, S19-S42.

Alesina, A., C. Favero, and F. Giavazzi (2019). Effects of austerity: Expenditure-and tax-based approaches. Journal of Economic Perspectives 33(2), 141-62.

Andersen, S., J. Y. Campbell, K. M. Nielsen, and T. Ramadorai (2020). Sources of inaction in household finance: Evidence from the danish mortgage market. American Economic Review (forthcoming).

Anderson, E. T. and D. I. Simester (2010). Price stickiness and customer antagonism. The Quarterly Journal of Economics 125(2), 729-765.

Andrade, P. and F. Ferroni (2019). Delphic and odyssean monetary policy shocks: Evidence from the euro area. Unpublished Manuscript.

Andre, P., C. Pizzinelli, C. Roth, and J. Wohlfart (2019). Subjective models of the macroeconomy: Evidence from experts and a representative sample. Available at SSRN 3355356.

Angeletos, G.-M. and C. Lian (2017). Dampening general equilibrium: From micro to macro. Technical report, National Bureau of Economic Research.

Armantier, O., W. Bruine de Bruin, S. Potter, G. Topa, W. van der Klaauw, and B. Zafar (2013). Measuring inflation expectations. Annual Review Economics 5(1), 273-301.

Armantier, O., W. Bruine de Bruin, G. Topa, W. Klaauw, and B. Zafar (2015). Inflation expectations and behavior: Do survey respondents act on their beliefs? International Economic Review 56(2), 505-536.

Atkinson, A. B. and J. Micklewright (1983). On the reliability of income data in the family expenditure survey 1970-1977. Journal of the Royal Statistical Society. Series A (General) 146(1), 33-61.

Attanasio, O. P. and G. Weber (1993). Consumption growth, the interest rate and aggregation. The Review of Economic Studies 60(3), 631-649.

Bachmann, R., T. O. Berg, and E. Sims (2015). Inflation expectations and readiness to spend: Cross-sectional evidence. American Economic Journal: Economic Policy 7(1), 1-35.

Bailey, M., E. Dávila, T. Kuchler, and J. Stroebel (2019). House price beliefs and mortgage leverage choice. The Review of Economic Studies (forthcoming).

Baker, S. R., N. Bloom, and S. J. Davis (2016). Measuring economic policy uncertainty. Quarterly Journal of Economics (forthcoming).

Barsky, R. B., C. Boehm, C. L. House, and M. S. Kimball (2016). Monetary policy and durable goods. Unpublished Manuscript, University of Michigan 97(3), 984-998.

Barsky, R. B., C. L. House, and M. S. Kimball (2007). Sticky-price models and durable goods. The American economic review 97(3), 984-998. 
Beraja, M., A. Fuster, E. Hurst, and J. Vavra (2019). Regional heterogeneity and the refinancing channel of monetary policy. The Quarterly Journal of Economics 134(1), 109-183.

Bernanke, B. S. (2007). Inflation expectations and inflation forecasting. Speech 306, Board of Governors of the Federal Reserve System (U.S.).

Besley, T. J. and H. S. Rosen (1999). Sales taxes and prices: an empirical analysis. National Tax Journal 52(2), 157-178.

Bundesbank, D. (2019). Household wealth and finances in germany: Results of the 2017 survey. Deutsche Bundesbank Monthly Report (April 2019).

Burke, M. A. and A. Ozdagli (2014). Household inflation expectations and consumer spending: evidence from panel data. Unpublished Manuscript, Federal Reserve Bank of Boston 13(25), $1-43$.

Campbell, J. R., C. L. Evans, J. D. Fisher, and A. Justiniano (2012). Macroeconomic effects of federal reserve forward guidance. Brookings Papers on Economic Activity, 1-80.

Cashin, D. (2016). The household expenditure response to a consumption tax rate increase. Unpublished Manuscript, Federal Reserve Board.

Cavallo, A., G. Cruces, and R. Perez-Truglia (2017). Inflation expectations, learning, and supermarket prices: Evidence from survey experiments. American Economic Journal: Macroeconomics 9(3), 1-35.

CDU (2005). Deutschlands Chancen nutzen. Wachstum. Arbeit. Sicherheit. Electoral Manifest.

Christelis, D., D. Georgarakos, T. Jappelli, and M. van Rooij (2016). Trust in the central bank and inflation expectations. Unpublished manuscript, ECB.

Coibion, O., D. Georgarakos, Y. Gorodnichenko, and M. Weber (2020). Forward guidance and household expectations. Technical report, National Bureau of Economic Research.

Coibion, O., Y. Gorodnichenko, and M. Weber (2019). Monetary policy communications and their effects on household inflation expectations. Technical report, National Bureau of Economic Research.

Coibion, O., Y. Gorodnichenko, and M. Weber (2020a). The cost of the covid-19 crisis: Lockdowns, macroeconomic expectations, and consumer spending. Technical report, National Bureau of Economic Research.

Coibion, O., Y. Gorodnichenko, and M. Weber (2020b). Labor markets during the covid-19 crisis: A preliminary view. Technical report, National Bureau of Economic Research.

Correia, I., E. Farhi, J. P. Nicolini, and P. Teles (2013). Unconventional fiscal policy at the zero bound. American Economic Review 103(4), 1172-1211.

Crossley, T., H. Low, and C. Sleeman (2014). Using a temporary indirect tax cut as a fiscal stimulus: evidence from the UK. Unpublished Manuscript, University of Essex.

Crump, R. K., S. Eusepi, A. Tambalotti, and G. Topa (2015). Subjective intertemporal substitution. FRB of New York Staff Report (734).

D'Acunto, F. (2014). Basic education in the long run: Innovation, investments. Technical report, and finance. Working Paper.

D'Acunto, F. (2018). Tear down this wall street: Anti-market rhetoric, motivated beliefs, and investment. Working Paper.

D'Acunto, F., D. Hoang, M. Paloviita, and M. Weber (2019a). Cognitive abilities and inflation expectations. AEA Papers 85 Proceedings (forthcoming).

D'Acunto, F., D. Hoang, M. Paloviita, and M. Weber (2019b). Human frictions in the transmission of economic policies. Working Paper.

D'Acunto, F., D. Hoang, M. Paloviita, and M. Weber (2020). Iq, expectations, and choice. Working Paper.

D'Acunto, F., D. Hoang, and M. Weber (2018). Unconventional fiscal policy. AEA Papers and Proceedings 108.

D'Acunto, F., U. Malmendier, J. Ospina, and M. Weber (2019). Perceived inflation, frequent price changes, and inflation expectations. Working Paper.

D'Acunto, F., U. Malmendier, and M. Weber (2018). Gender roles distort women's economic expectations. Working Paper.

D'Acunto, F., M. Prokopczuk, and M. Weber (2018). Historical antisemitism, ethnic 
specialization, and financial development. The Review of Economic Studies 86(3), 1170-1206.

Del Negro, M., M. P. Giannoni, and C. Patterson (2015). The forward guidance puzzle. FRB of New York Staff Report (574).

Di Maggio, M. and A. Kermani (2019). Unemployment insurance as an automatic stabilizer: The financial channel. Working Paper.

Di Maggio, M., A. Kermani, and C. J. Palmer (2020). How quantitative easing works: Evidence on the refinancing channel. The Review of Economic Studies 87(3), 1498-1528.

Doepke, M. and M. Schneider (2006). Inflation and the redistribution of nominal wealth. Journal of Political Economy 114(6), 1069-1097.

Eggertsson, G. B. (2008). Great expectations and the end of the depression. The American Economic Review 98(4), 1476-1516.

Eggertsson, G. B. and M. Woodford (2003). The zero bound on interest rates and optimal monetary policy. Brookings Papers on Economic Activity 2003(1), 139-211.

Farhi, E., G. Gopinath, and O. Itskhoki (2014). Fiscal devaluations. The Review of Economic Studies 81(2), 725-760.

Farhi, E. and I. Werning (2018). Monetary policy, bounded rationality, and incomplete markets. Working Paper.

Feldstein, M. (2002). The role for discretionary fiscal policy in a low interest rate environment. Technical report, National Bureau of Economic Research.

Fuchs-Schuendeln, N. and T. A. Hassan (2016). Natural experiments in macroeconomics. In Handbook of macroeconomics, Volume 2, pp. 923-1012. Elsevier.

Gabaix, X. (2016). A behavioral new keynesian model. Technical report, National Bureau of Economic Research.

Gorodnichenko, Y. and M. Weber (2016). Are sticky prices costly? evidence from the stock market. American Economic Review 106(1), 165-99.

Hall, R. E. (2011). The long slump. American Economic Review 101(2), 431-469.

Hurd, M. D. and S. Rohwedder (2012). Measuring total household spending in a monthly internet survey: Evidence from the American Life Panel. Technical report, National Bureau of Economic Research.

Ichiue, H. and S. Nishiguchi (2015). Inflation expectations and consumer spending at the zero bound: Micro evidence. Economic Inquiry 53(2), 1086-1107.

Ilut, C. and R. Valchev (2017). Economic agents as imperfect problem solvers. Unpublished Manuscript, Boston College.

Jalil, A. and G. Rua (2016). Inflation expectations and recovery from the depression in 1933: Evidence from the narrative record. Explorations in Economic History, forthcoming.

Jappelli, T. and L. Pistaferri (2014). Fiscal policy and MPC heterogeneity. American Economic Journal: Macroeconomics 6(4), 107-136.

Jonung, L. (1981). Perceived and expected rates of inflation in Sweden. The American Economic Review 71(5), 961-968.

Kaplan, G., B. Moll, and G. L. Violante (2018). Monetary policy according to hank. American Economic Review 108(3), 697-743.

Kreiner, C. T., D. D. Lassen, and S. Leth-Petersen (2013). Measuring the accuracy of survey responses using administrative register data: Evidence from denmark. Technical report, National Bureau of Economic Research.

Kuchler, T. and B. Zafar (2018). Personal experiences and expectations about aggregate outcomes. Journal of Finance (forthcoming).

Kuhnen, C. M. and A. C. Miu (2017). Socioeconomic status and learning from financial information. Journal of Financial Economics 124(2), 349-372.

Leth-Petersen, S. (2010). Intertemporal consumption and credit constraints: Does total expenditure respond to an exogenous shock to credit? American Economic Review 100(3), $1080-1103$.

Malmendier, U. and S. Nagel (2009). Learning from inflation experiences. Unpublished manuscript, UC Berkeley. 
Menz, J.-O. and P. Poppitz (2013). Household disagreement on inflation expectations and socioeconomic media exposure in Germany. Unpublished Manuscript, Deutsche Bundesbank.

Nakamura, E., J. Steinsson, P. Sun, and D. Villar (2016). The elusive costs of inflation: Price dispersion during the US great inflation. Unpublished Manuscript, Columbia University.

Poterba, J. M. (1996). Retail price reactions to changes in state and local sales taxes. National Tax Journal 49(2), 165-176.

Romer, C. D. and D. H. Romer (2010). The macroeconomic effects of tax changes: Estimates based on a new measure of fiscal shocks. The American Economic Review 100(3), 763-801.

Romer, C. D. and D. H. Romer (2013). The missing transmission mechanism in the monetary explanation of the Great Depression. The American Economic Review 103(3), 66-72.

Roth, C. and J. Wohlfart (2019). How do expectations about the macroeconomy affect personal expectations and behavior? Review of Economics and Statistics (forthcoming).

Shapiro, M. D. (1991). Economic stimulant. Technical report, New York Times.

Slacalek, J., O. Tristani, and G. L. Violante (2020). Household balance sheet channels of monetary policy: A back of the envelope calculation for the euro area. Technical report, National Bureau of Economic Research.

SPD (2005). Vertrauen in Deutschland. Das Wahlmanifest der SPD. Electoral Manifest.

Stehle, R. M. (2006, June 23, 2006). Geplante Mehrwertsteuer-Anhebung treibt Inflation. Berliner Zeitung.

Vellekoop, N. and M. Wiederholt (2017). Inflation expectations and choices of households: Evidence from matched survey and administrative data. Unpublished Manuscript, University of Frankfurt.

Weber, A. (2006, June 23, 2006). Weber haelt Zinserhoehung der EZB fuer notwendig. Handelsblatt.

Woodford, M. (2018). Monetary policy analysis when planning horizons are finite. NBER Macro Annual (forthcoming). 
Figure 2: Expected Increase in Inflation: Germany and European Countries
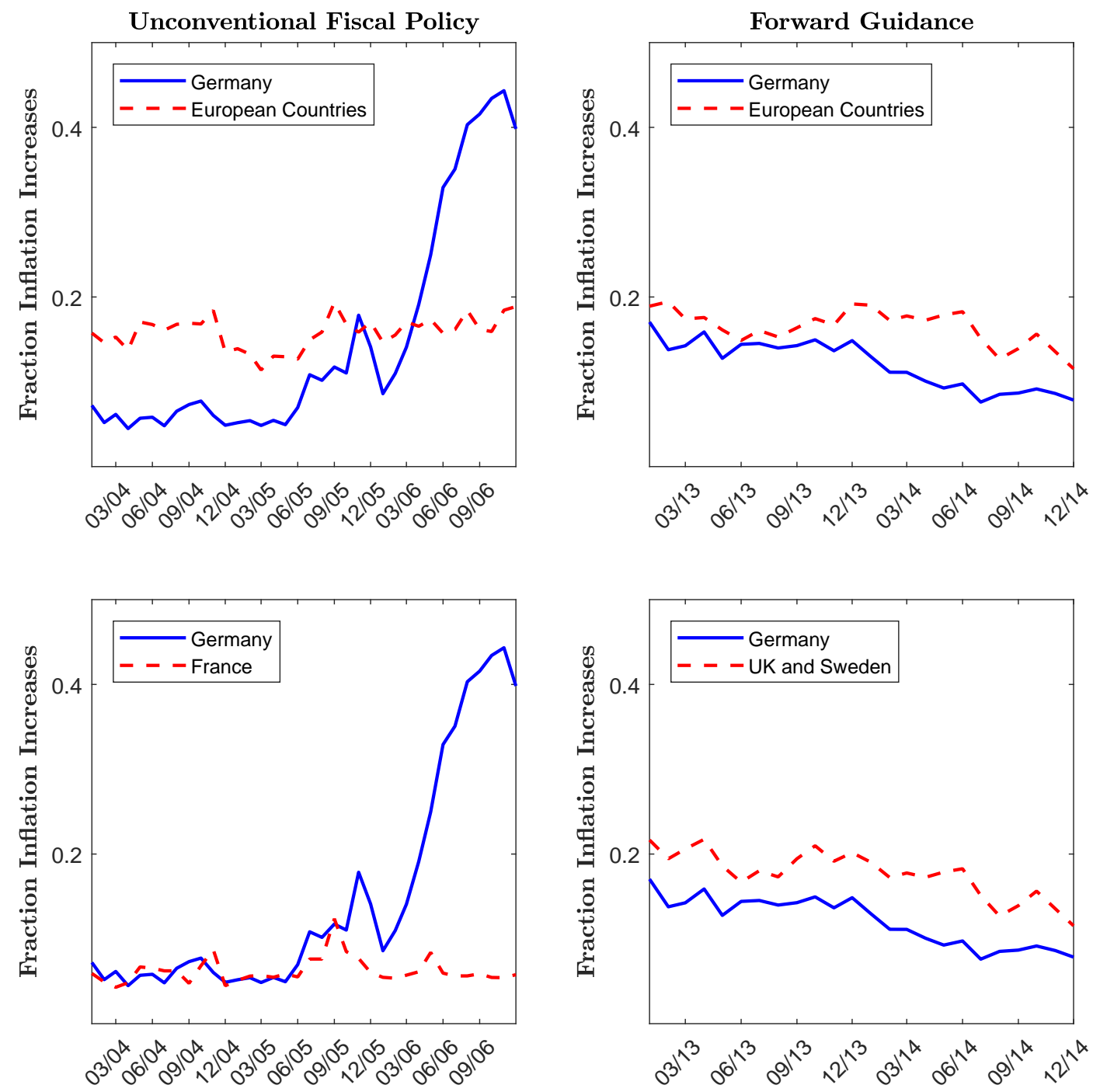

This figure plots average monthly inflation expectations over time. We use the confidential micro data underlying the GfK Consumer Climate MAXX survey to construct the variables for Germany and similar data from national statistical agencies and GfK subsidiaries for the United Kingdom, Sweden, and France. GfK asks a representative sample of 2,000 households how consumer prices will evolve in the next 12 months compared to the previous 12 months. We create a dummy variable which equals 1 when a household expects inflation to increase. The sample periods are January 2004-December 2006 and January 2013-December 2014. 
Figure 3: Readiness to Spend on Durables: Germany and European Countries
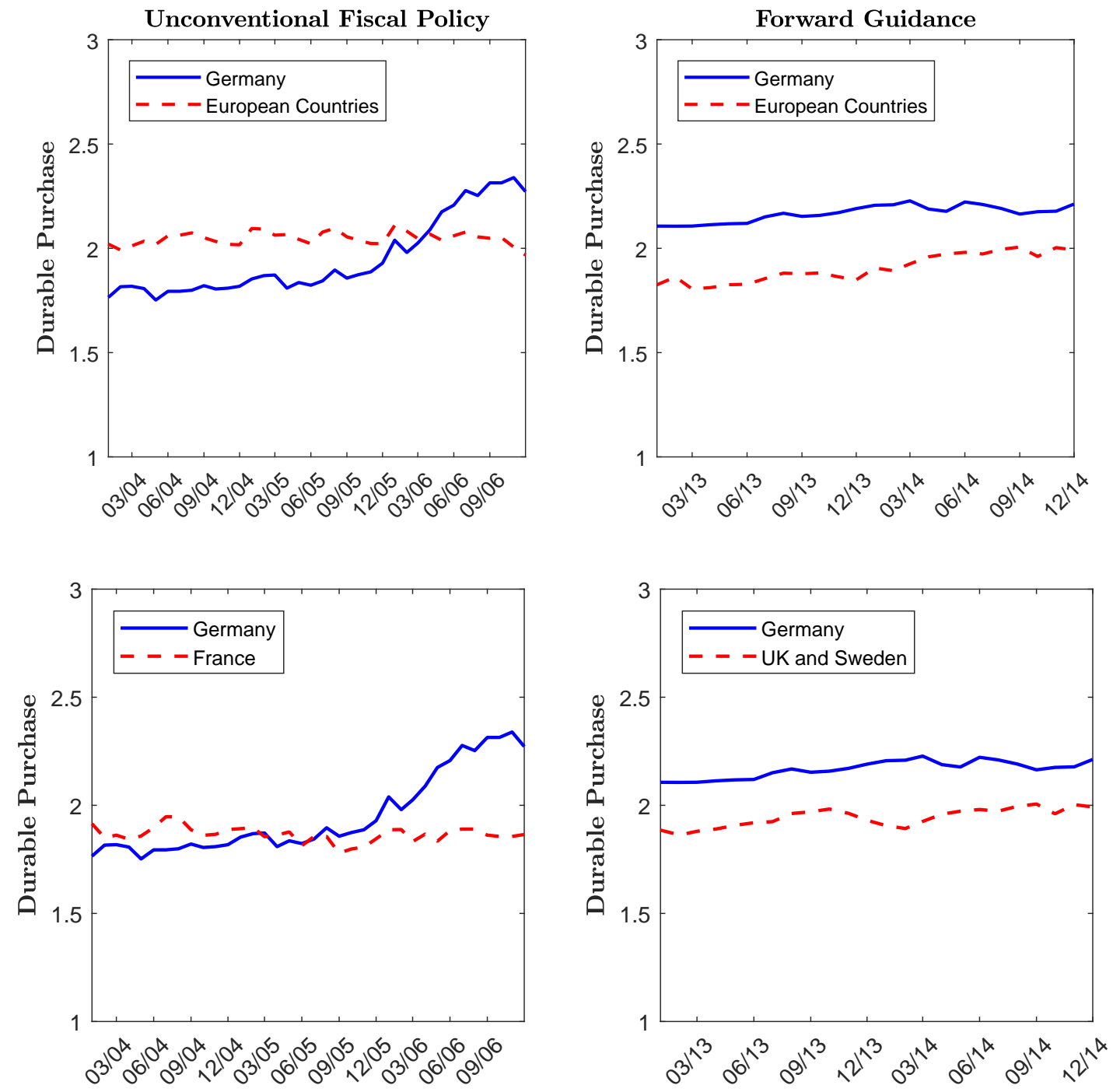

This figure plots the average monthly readiness to purchase durables over time. We use the confidential micro data underlying the GfK Consumer Climate MAXX survey to construct these variables for Germany and similar data from national statistical agencies and GfK subsidiaries for the United Kingdom, Sweden, and France. GfK asks a representative sample of 2,000 households whether it is a good time to purchase durables given the current economic conditions. Higher values correspond to better times to purchase durables. The sample periods are January 2004December 2006 and January 2013-December 2014. 
Figure 4: Common Support of Treated and Matched Households

Panel A. Unconventional Fiscal Policy

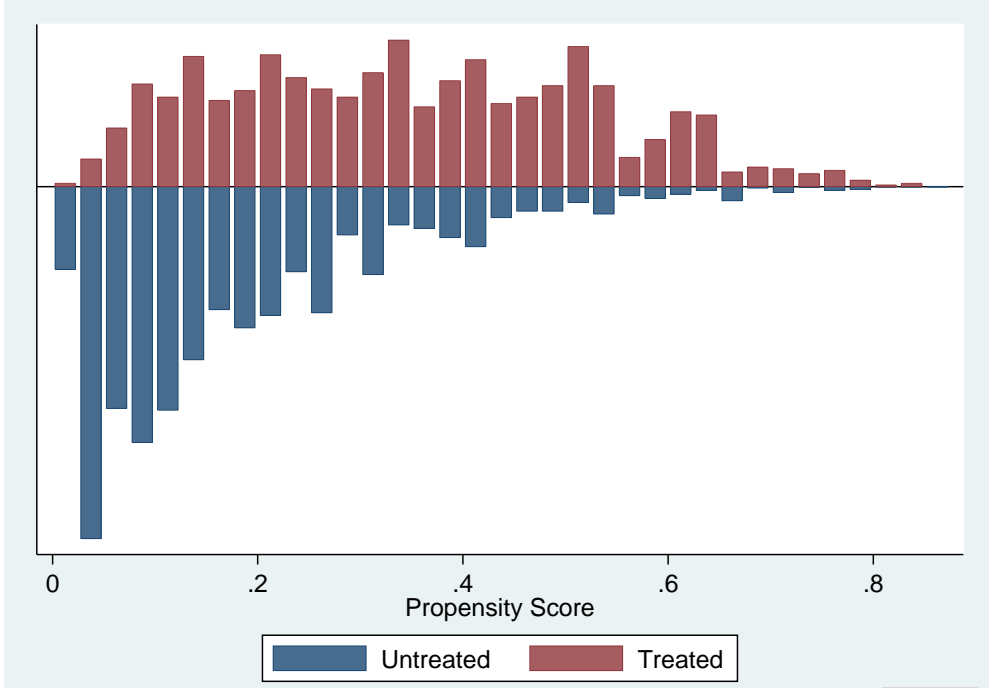

Panel B. Forward Guidance

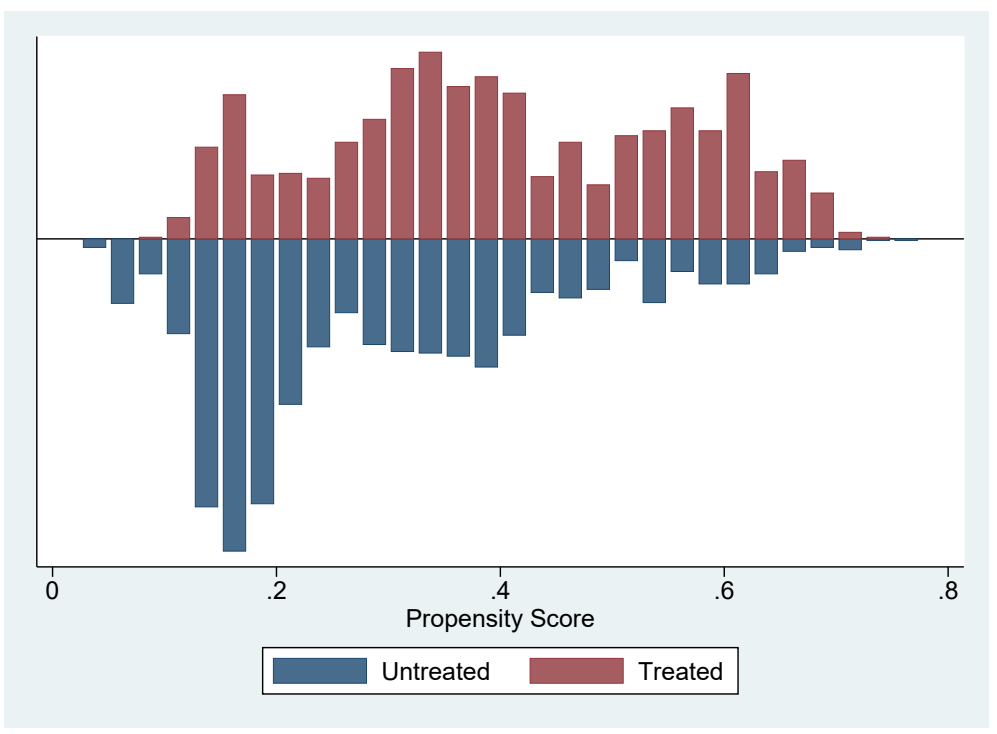

This figure plots the number of households in the untreated (blue) and treated (red) groups across forty equal-length partitions of the distribution of the propensity score in the baseline months (June 2005 and March 2013) for the difference-in-differences analyses. We estimate the propensity score with a logit specification whose outcome variable is the indicator for whether a household is in the treated or control group. The controls are the observables we use for the matching of households: age group, gender, education group, income group, and social status group. The treated group includes German households, whereas the control group includes households from the UK, France, and Sweden in Panel $A$ and from the UK and Sweden in Panel B. 


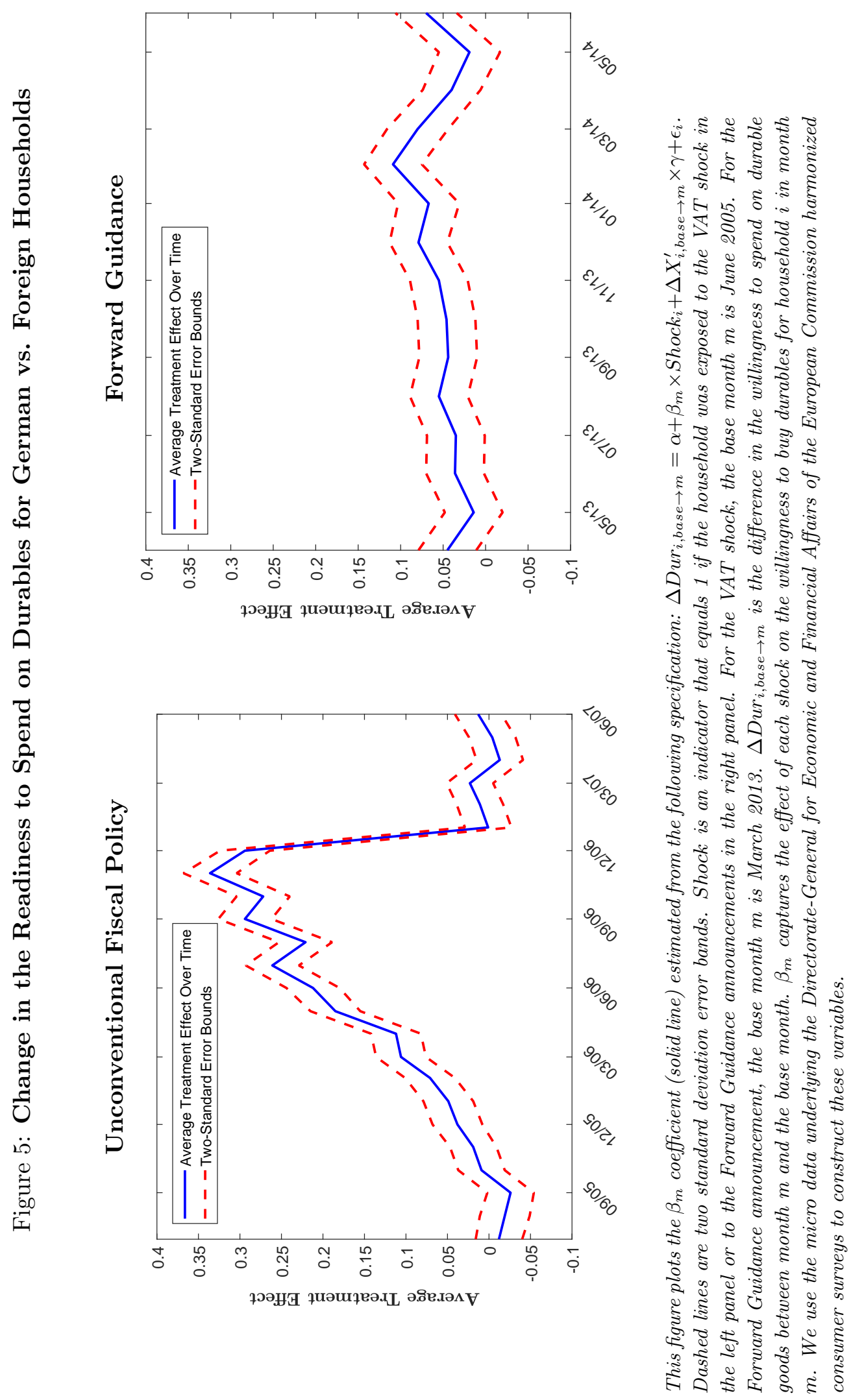


Figure 6: Effect of Unconventional Fiscal Policy by Sophistication and Demographics
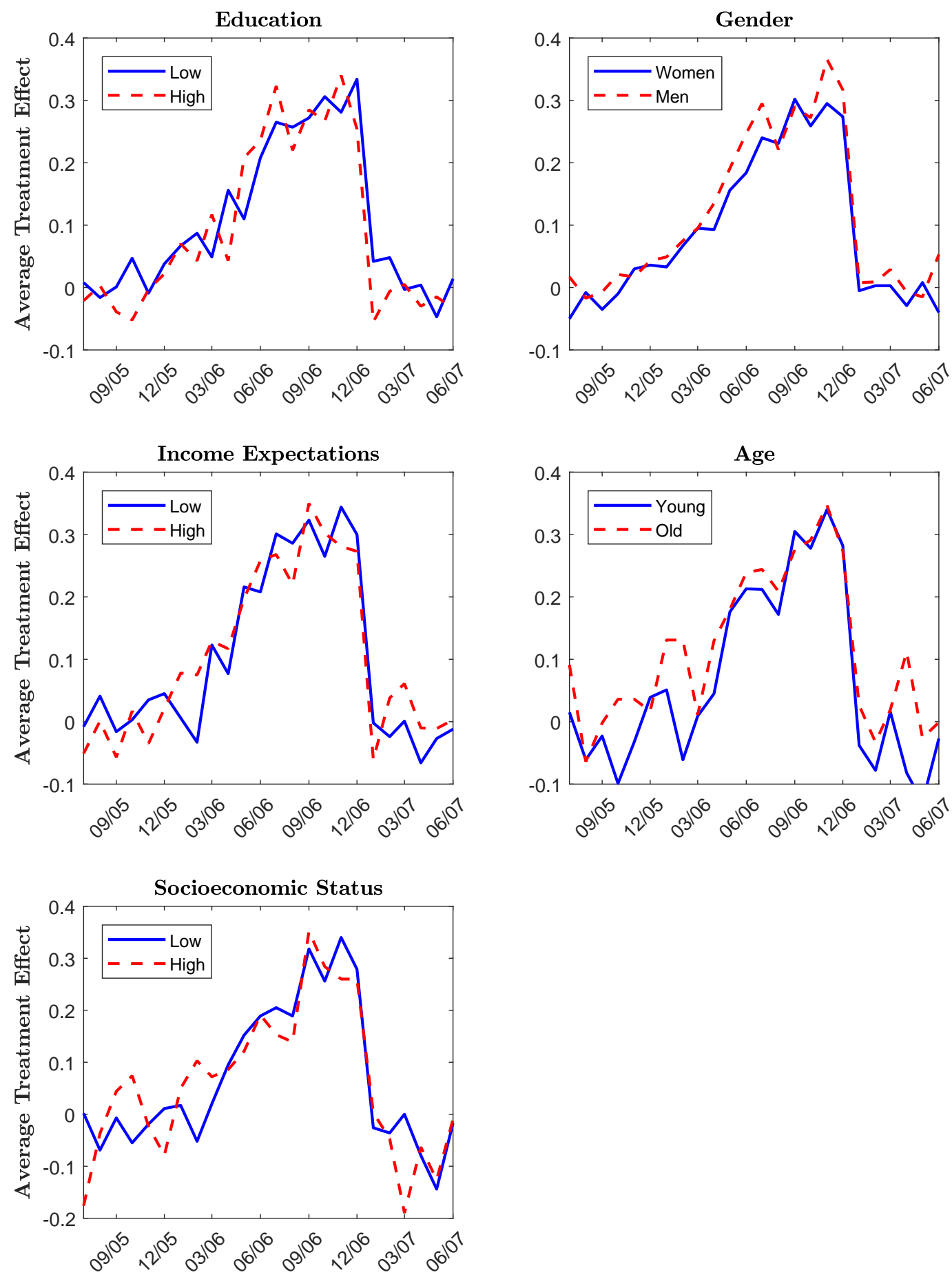

This figure plots the $\beta_{m}$ coefficient (solid line) estimated from the following specification: $\Delta$ Dur $r_{i, 06 / 2005 \rightarrow m}=\alpha+\beta_{m} \times$ $V A T$ shock ${ }_{i}+\Delta X_{i, 06 / 2005 \rightarrow m}^{\prime} \times \gamma+\epsilon_{i}$, for different sample splits by demographic characteristics. $\Delta$ Dur $_{i, 06 / 2005 \rightarrow m}$ is the difference in the willingness to spend on durable goods between month $m$ and June 2005, VATshock $k_{i}$ is an indicator which equals 1 if the household was exposed to the VAT shock, $\beta_{m}$ captures the effect of the VAT shock on the willingness to buy durables for household $i$ in month $m$, and $\Delta X_{i, 06 / 2005 \rightarrow m}^{\prime}$ is the difference in a set of observables between month $m$ and the baseline month. We use the micro data underlying the Directorate-General for Economic and Financial Affairs of the European Commission harmonized consumer surveys to construct these variables. 
Figure 7: Effect of Unconventional Fiscal Policy by Proxies of Financial Constraints
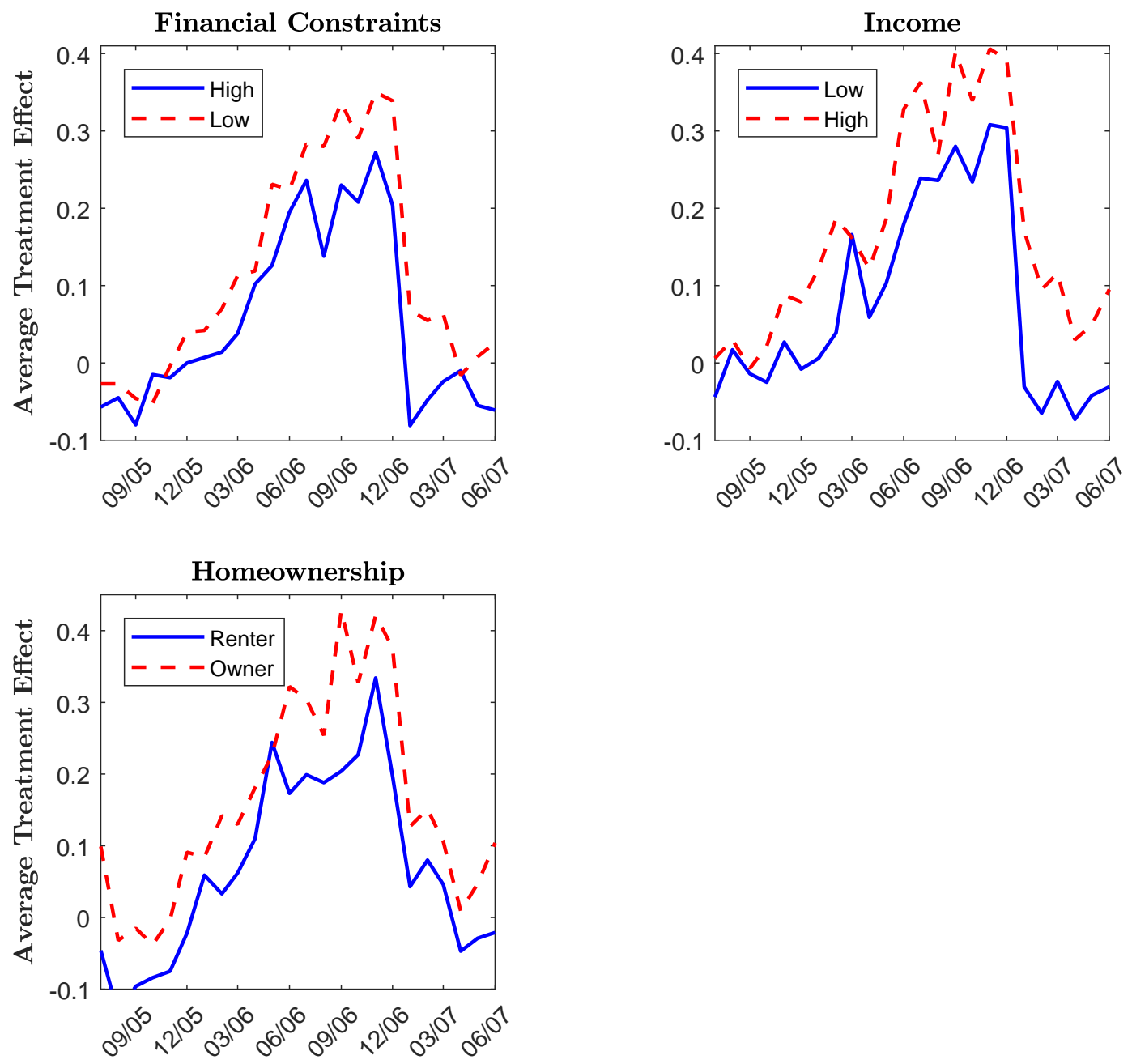

This figure plots the $\beta_{m}$ coefficient (solid line) estimated from the following specification: $\Delta D_{u} r_{i, 06 / 2005 \rightarrow m}=\alpha+$ $\beta_{m} \times V$ ATshock $k_{i}+\Delta X_{i, 06 / 2005 \rightarrow m}^{\prime} \times \gamma+\epsilon_{i}$, for different sample splits by financial constraints. $\Delta$ Dur $r_{i, 06 / 2005 \rightarrow m}$ is the difference in the willingness to spend on durable goods between month $m$ and June 2005, VATshock ${ }_{i}$ is an indicator which equals 1 if the household was exposed to the VAT shock, $\beta_{m}$ captures the effect of the VAT shock on the willingness to buy durables for household $i$ in month $m$, and $\Delta X_{i, 06 / 2005 \rightarrow m}^{\prime}$ is the difference in a set of observables between month $m$ and the baseline month. We use the micro data underlying the Directorate-General for Economic and Financial Affairs of the European Commission harmonized consumer surveys to construct these variables. 
Figure 8: Effect of Forward Guidance by Sophistication and Demographics
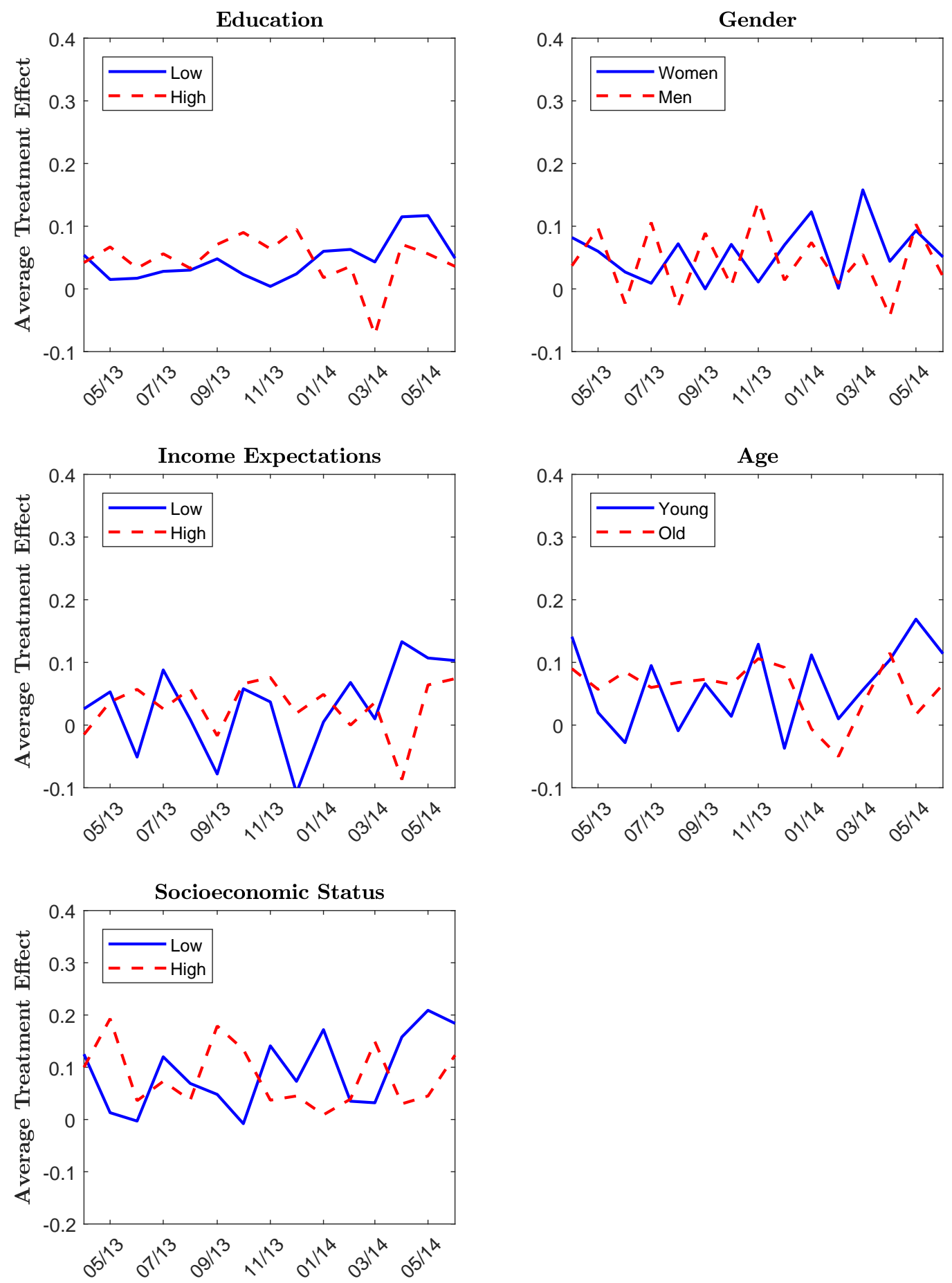

This figure plots $\beta_{m}$ coefficient (solid line) of $\Delta$ Dur $_{i, 03 / 2013 \rightarrow m}=\alpha+\beta_{m} \times V$ ATshock s $_{i}+\Delta X_{i, 03 / 2013 \rightarrow m}^{\prime} \times \gamma+\epsilon_{i}$, for different sample splits by demographics. $\Delta$ Dur $_{i, 03 / 2013 \rightarrow m}$ is the difference in the willingness to spend on durable

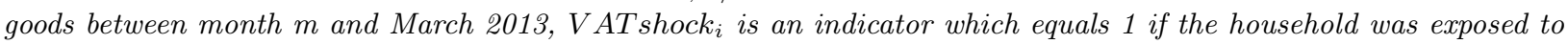
the VAT shock, $\beta_{m}$ captures the effect of the VAT shock on the willingness to buy durables for household $i$ in month $m$, and $\Delta X_{i, 03 / 2013 \rightarrow m}^{\prime}$ is the difference in a set of observables between month $m$ and the baseline month. We use the micro data underlying the Directorate-General for Economic and Financial Affairs of the European Commission harmonized consumer surveys to construct these variables. 
Figure 9: Effect of Forward Guidance by Proxies of Financial Constraints
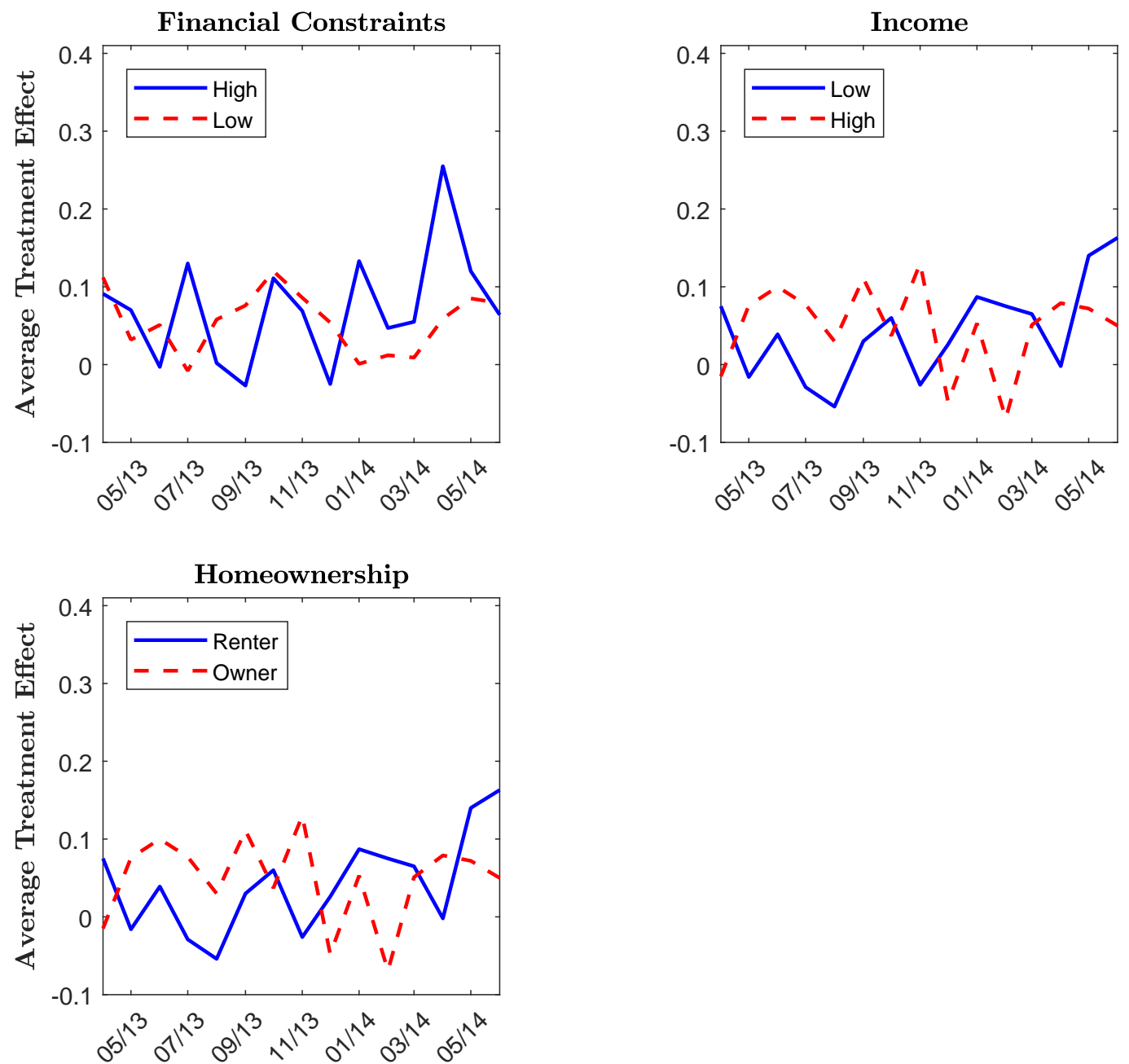

This figure plots $\beta_{m}$ coefficient (solid line) of $\Delta$ Dur $_{i, 03 / 2013 \rightarrow m}=\alpha+\beta_{m} \times V$ ATshock i $_{i}+\Delta X_{i, 03 / 2013 \rightarrow m}^{\prime} \times \gamma+\epsilon_{i}$, for different sample splits by financial constraints. $\Delta D_{\text {ur }}, 03 / 2013 \rightarrow m$ is the difference in the willingness to spend on durable goods between month $m$ and March 2013, VATshock $i$ is an indicator which equals 1 if the household was exposed to the VAT shock, $\beta_{m}$ captures the effect of the VAT shock on the willingness to buy durables for household $i$ in month $m$, and $\Delta X_{i, 03 / 2013 \rightarrow m}^{\prime}$ is the difference in a set of observables between month $m$ and the baseline month. We use the micro data underlying the Directorate-General for Economic and Financial Affairs of the European Commission harmonized consumer surveys to construct these variables. 


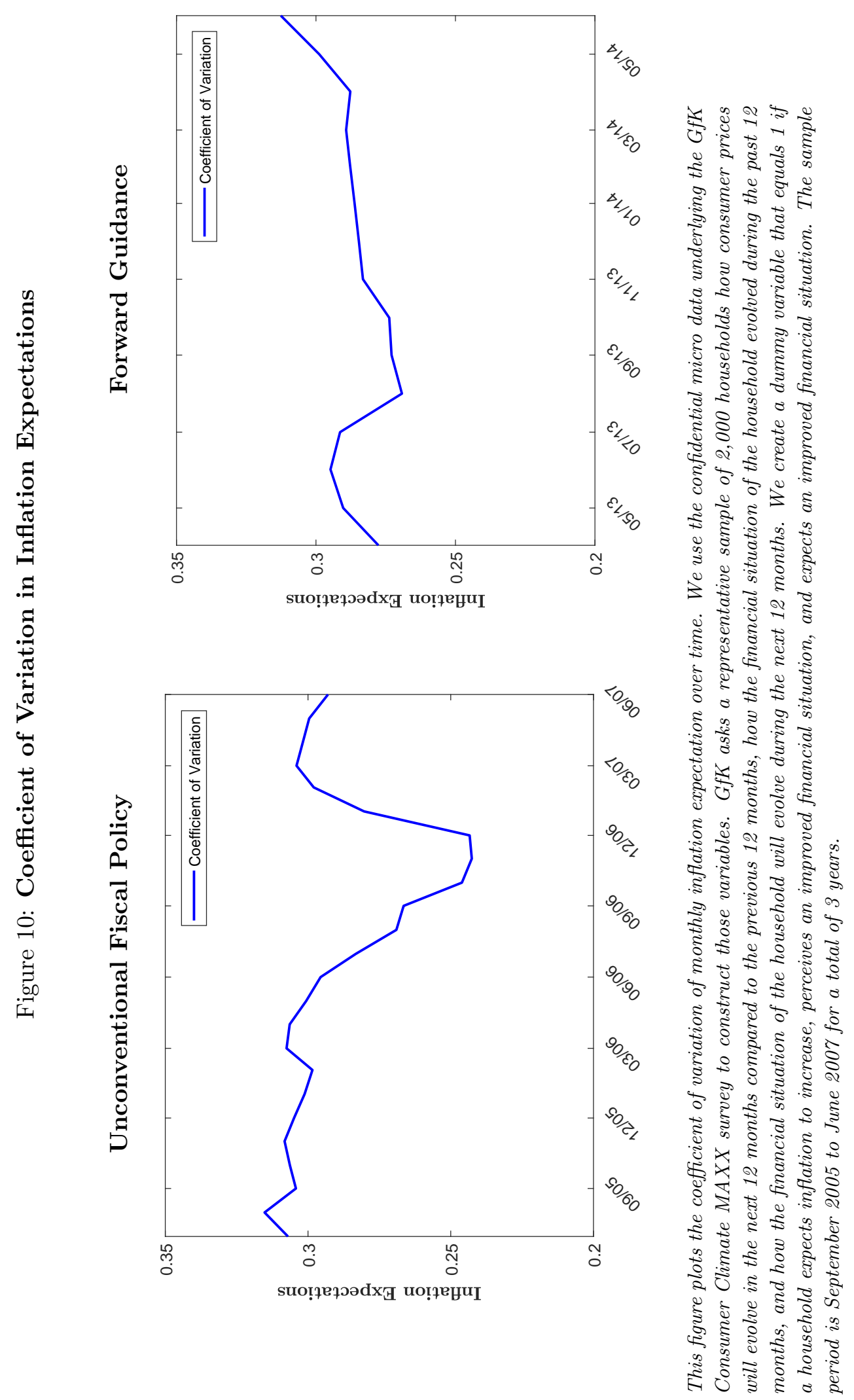


Figure 11: Channels of Unconventional Fiscal Policy: Income Effect?

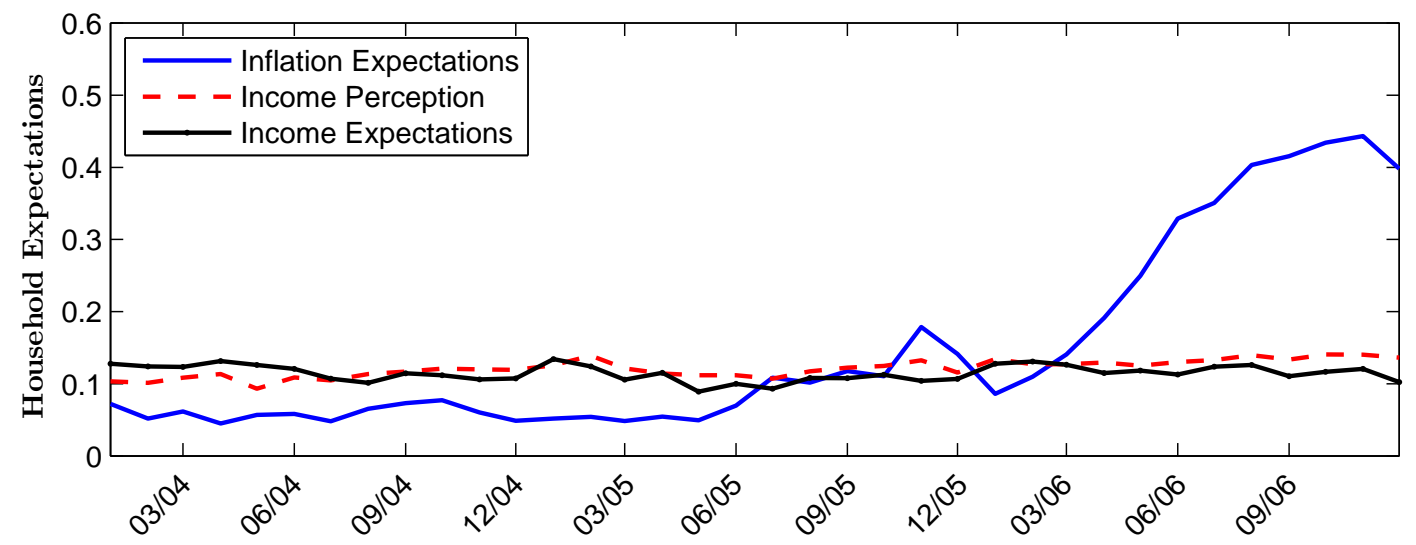

This figure plots average monthly inflation expectation, perception of past income, and expectation of future income over time. We use the confidential micro data underlying the GfK Consumer Climate MAXX survey to construct those variables. GfK asks a representative sample of 2,000 households how consumer prices will evolve in the next 12 months compared to the previous 12 months, how the financial situation of the household evolved during the past 12 months, and how the financial situation of the household will evolve during the next 12 months. We create a dummy variable that equals 1 if a household expects inflation to increase, perceives an improved financial situation, and expects an improved financial situation. The sample period is January 2004 to December 2006 for a total of 3 years.

Figure 12: Channels of Forward Guidance: Income Effect?

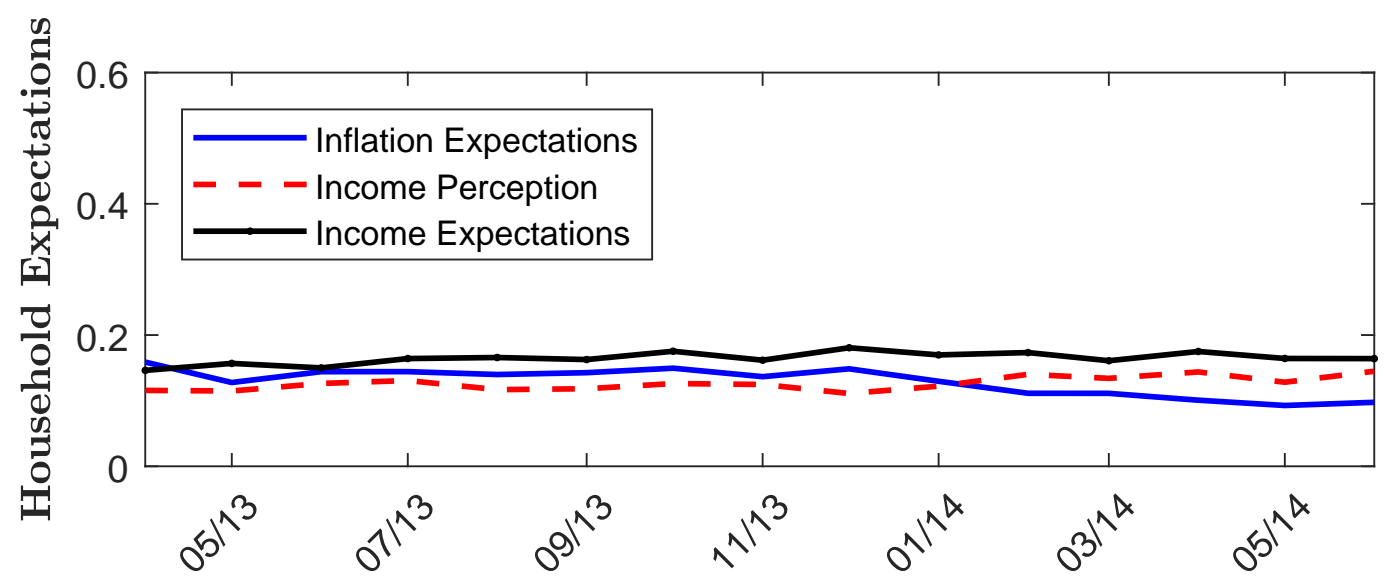

This figure plots average monthly inflation expectation, perception of past income, and expectation of future income over time. We use the confidential micro data underlying the GfK Consumer Climate MAXX survey to construct those variables. GfK asks a representative sample of 2,000 households how consumer prices will evolve in the next 12 months compared to the previous 12 months, how the financial situation of the household evolved during the past 12 months, and how the financial situation of the household will evolve during the next 12 months. We create a dummy variable that equals 1 if a household expects inflation to increase, perceives an improved financial situation, and expects an improved financial situation. The sample period is April 2013 to June 2014. 


\section{Table 1: Descriptive Statistics}

This table reports descriptive statistics for households' inflation expectations and readiness to purchase durables in Panel A; household demographics in Panel B; and household expectations and perceptions in Panel C. We use the confidential micro data underlying the GfK Consumer Climate survey to measure these variables. GfK asks a representative sample of 2,000 households questions about general economic expectations, income expectations, and willingness to buy in order to create an aggregate measure labeled "consumer climate." For Panel A, GfK asks whether it is a good time to purchase durables given the current economic conditions. GfK also asks how consumer prices will evolve in the next 12 months compared to the previous 12 months. Inflation increase is a dummy variable that equals 1 if a household replies that inflation will increase. GfK also asks how consumer prices evolved in the previous 12 months. See the online appendix for data sources and detailed survey questions. The sample period is January 2000 to February 2016.

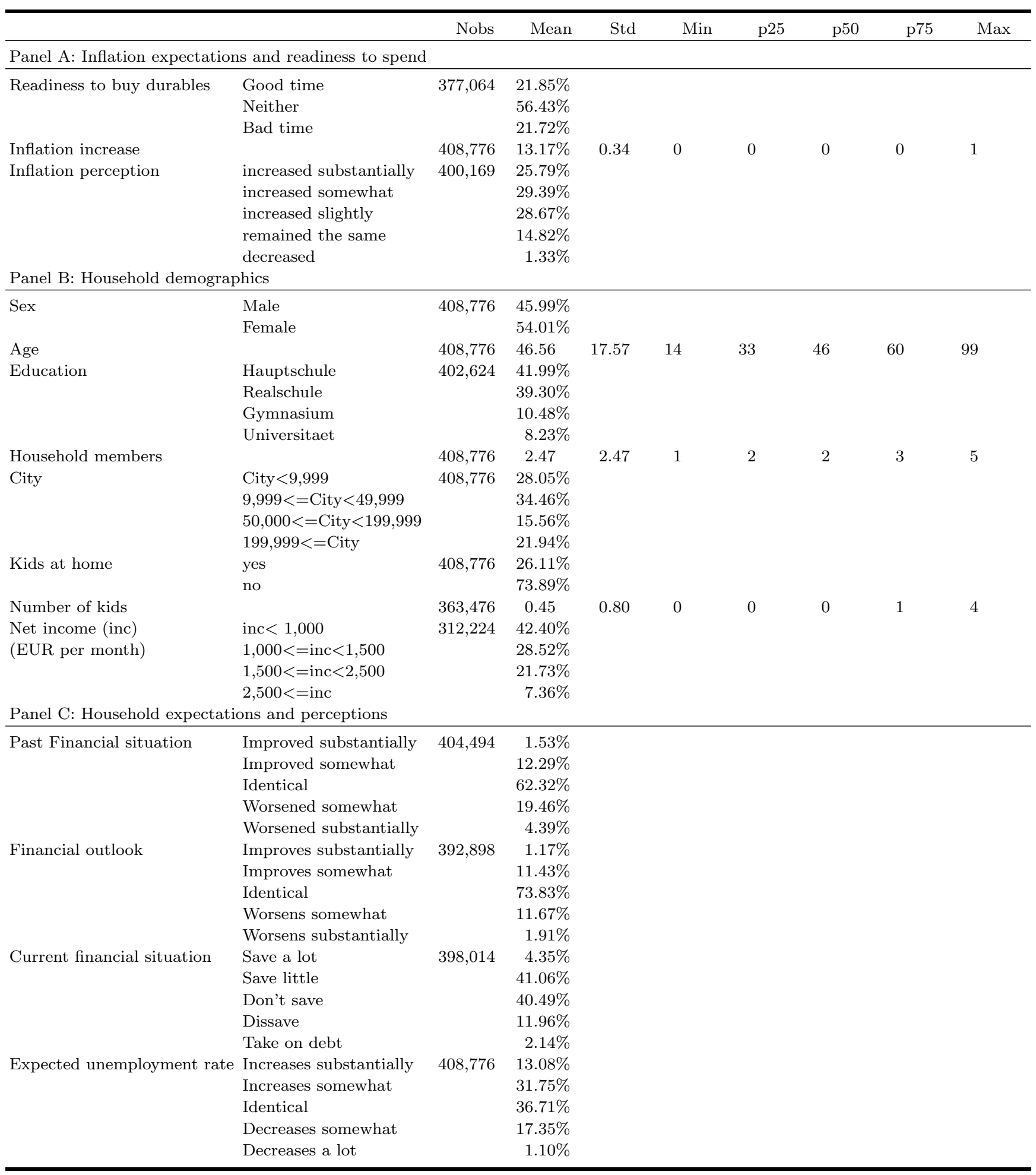


Table 2: Balancing of Variables - German and Foreign Households

This table describes the balancing of the observables we use to match treated and control households during the unconventional fiscal policy period (11/2005-12/2006) in Panel $A$ and during the forward guidance period in Panel B (03/2013-06/2014) for the difference-in-differences analysis. For each variable, columns (1) and (4) report the mean within the pool of treated German households in the raw and matched samples. Columns (2) and (5) report the mean within the pool of control households (UK, France, and Sweden) in the raw and matched samples. Columns (3) and (6) report the results for a two-sided t-test whose null hypothesis is that the means across groups are equal.

Unmatched Sample

\begin{tabular}{|c|c|c|c|c|c|c|}
\hline Variable & $\begin{array}{c}\text { Mean } \\
\text { Treated } \\
(1)\end{array}$ & $\begin{array}{c}\text { Mean } \\
\text { Control } \\
(2)\end{array}$ & $\begin{array}{r}\text { t-stats } \\
(3)\end{array}$ & $\begin{array}{c}\text { Mean } \\
\text { Treated } \\
(4)\end{array}$ & $\begin{array}{c}\text { Mean } \\
\text { Control } \\
(5)\end{array}$ & $\begin{array}{r}\text { t-stats } \\
(6)\end{array}$ \\
\hline & \multicolumn{6}{|c|}{ Panel A: Unconventional Fiscal Policy Period } \\
\hline Age (four groups) & 2.38 & 2.49 & -15.32 & 2.38 & 2.38 & 0.00 \\
\hline Male & 0.46 & 0.44 & 5.61 & 0.46 & 0.46 & -0.01 \\
\hline Education (three groups) & 1.77 & 2.32 & -109.47 & 1.77 & 1.77 & 0.00 \\
\hline Income (four quartiles) & 2.36 & 2.77 & -41.53 & 2.36 & 2.36 & 0.01 \\
\hline Social Status (three groups) & 2.65 & 1.93 & 107.50 & 2.65 & 2.65 & 0.00 \\
\hline Nobs in common support & & & & 28,642 & 95,890 & \\
\hline
\end{tabular}

Panel B: Forward Guidance Period

\begin{tabular}{lccrccc}
\cline { 2 - 6 } Age (four groups) & 2.57 & 2.46 & 13.48 & 2.57 & 2.57 & 0.00 \\
Male & 0.46 & 0.49 & -7.96 & 0.46 & 0.46 & 0.00 \\
Education (three groups) & 1.85 & 2.43 & -105.57 & 1.85 & 1.85 & 0.00 \\
Income (four quartiles) & 2.59 & 3.39 & -53.60 & 2.59 & 2.59 & 0.00 \\
Social Status (three groups) & 2.65 & 2.41 & 30.89 & 2.65 & 2.65 & 0.00 \\
\hline Nobs in common support & & & & 24,321 & 49,535 & \\
\hline
\end{tabular}




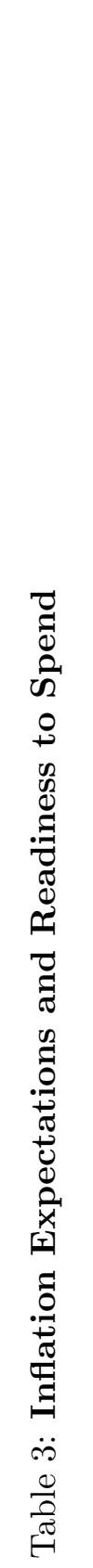

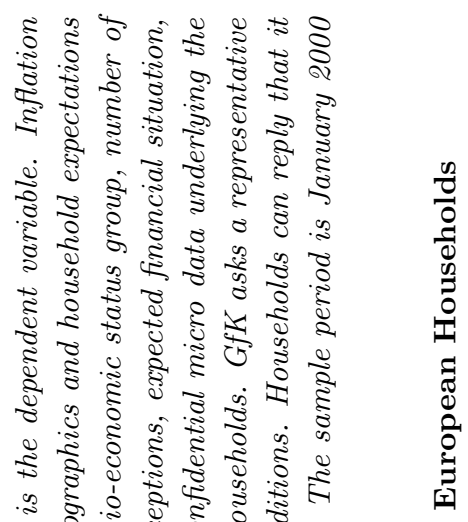

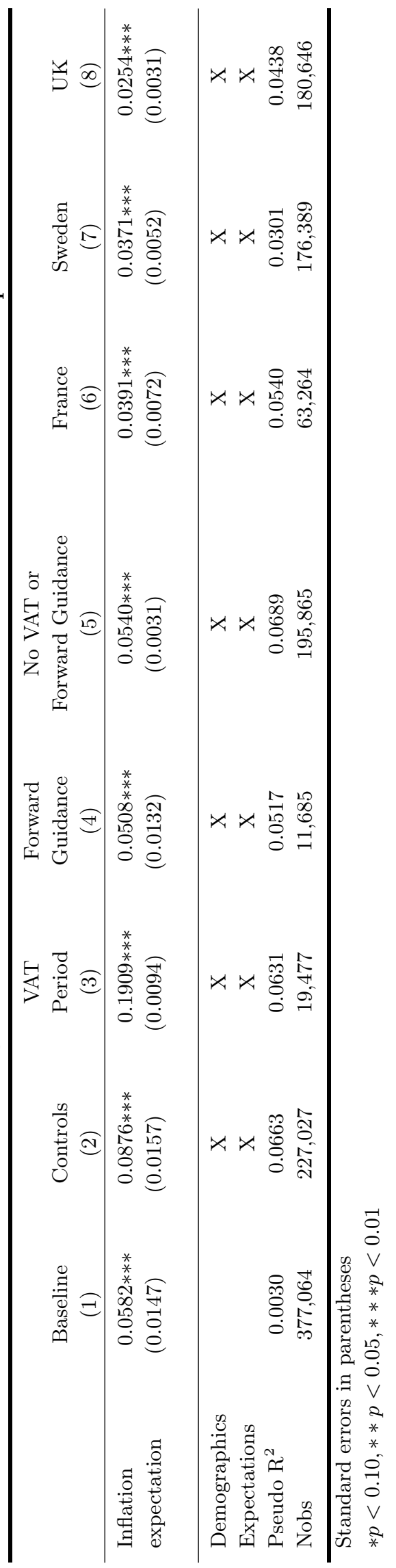




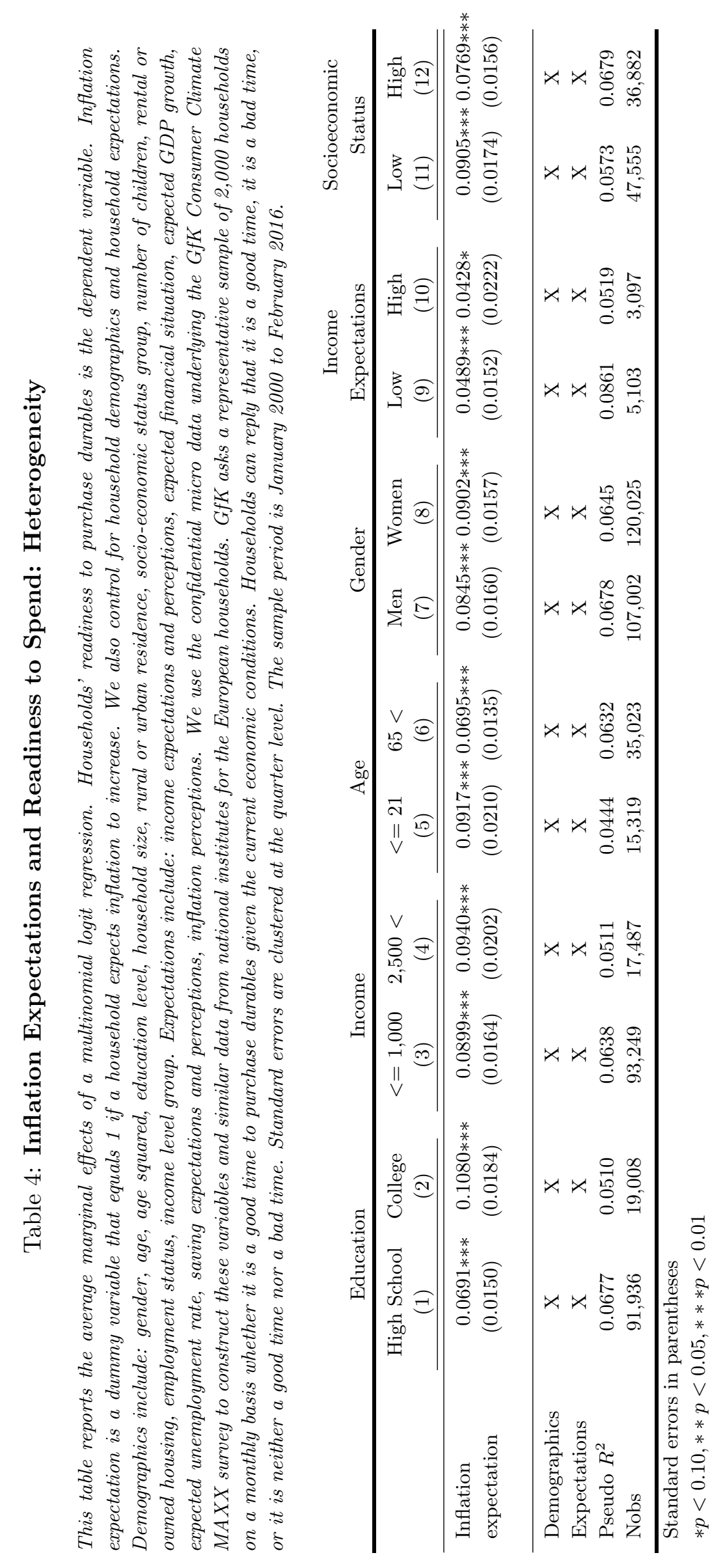


Table 5: Inflation Expectations and Readiness to Save

This table reports the average marginal effects of a multinomial logit regression. Households' readiness to save is the dependent variable. Inflation expectation is a dummy variable that equals 1 if a household expect higher inflation. Demographics include: gender, age, age squared, education level, household size, rural or urban residence, socio-economic status group, number of children, rental or owned housing, employment status, income level group. Expectations include: income expectations and perceptions, expected financial situation, expected GDP growth, expected unemployment rate, saving expectations and perceptions, inflation perceptions. We use the confidential micro data underlying the GfK Consumer Climate MAXX survey to construct these variables and similar data from national institutes for the European households. GfK asks a representative sample of 2,000 households on a monthly basis whether it is a good time to save given the current economic conditions. Households can reply that it is a good time, it is a bad time, or it is neither a good time nor a bad time. Standard errors are clustered at the quarter level. The sample period is January 2000 to February 2016.

\begin{tabular}{lccc}
\hline & Not at all & Not really & Good time \\
& $(1)$ & $(2)$ & $(3)$ \\
\hline Inflation expectation & $0.0282 * * *$ & 0.0015 & $-0.0297 * * *$ \\
& $(0.0027)$ & $(0.0057)$ & $(0.0069)$ \\
& & & \\
\hline Demographics & $\mathrm{X}$ & $\mathrm{X}$ & $\mathrm{X}$ \\
Individual expectations & $\mathrm{X}$ & $\mathrm{X}$ & $\mathrm{X}$ \\
Pseudo R & & 0.1471 & \\
Nobs & & 242,820 & \\
\hline
\end{tabular}

Standard errors in parentheses
$* p<0.10, * * p<0.05, * * * p<0.01$ 


\title{
Online Appendix: Managing Households' Expectations with Unconventional Policiess
}

\author{
Francesco D'Acunto, Daniel Hoang, and Michael Weber
}

Not for Publication

\section{A.1 Survey Questions}

Below we report the original survey questions with answer choices for Germany, the English translation, and the harmonized surveys from the Directorate-General for Economic and Financial Affairs of the European Commission harmonized consumer surveys used in Section II for the matching estimator.

\section{A. Germany}

Question 1 Wie hat sich Ihrer Meinung nach die "allgemeine Wirtschaftslage" in Deutschland in den letzten 12 Monaten entwickelt?

Sie ...

- hat sich wesentlich verbessert

- hat sich etwas verbessert

- ist in etwa gleich geblieben

- hat sich etwas verschlechtert

- hat sich wesentlich verschlechtert

- weiss nicht

Question 2 Wie haben sich Ihrer Ansicht nach die Verbraucherpreise in den letzten 12 Monaten entwickelt?

Sie sind $\ldots$

- stark gestiegen

- in Massen gestiegen

- leicht gestiegen

- in etwa gleich geblieben

- gesunken

- weiss nicht

Question 3 Wie werden sich Ihrer Ansicht nach die Verbraucherpreise in den kommenden 12 Monaten im Vergleich zu den letzten 12 Monaten entwickeln?

Sie werden ...

- staerker als bisher steigen

- etwa im gleichen Masse wie bisher steigen

- weniger stark als bisher steigen 
- in etwa gleich bleiben

- gesunken

- weiss nicht

Question 4 Wie hat sich die finanzielle Lage Ihres Haushaltes in den letzten 12 Monaten entwickelt?

Sie ...

- hat sich wesentlich verbessert

- hat sich etwas verbessert

- ist in etwa gleichgeblieben

- hat sich etwas verschlechtert

- hat sich wesentlich verschlechtert

- weiss nicht

Question 5 Wie wird sich Ihrer Ansicht nach die finanzielle Lage Ihres Haushaltes in den kommenden 12 Monaten entwickeln?

Sie wird ...

- sich wesentlich verbessern

- sich etwas verbessern

- in etwa gleichbleiben

- sich etwas verschlechtern

- sich wesentlich verschlechtern

- weiss nicht

Question 6 Wie wird sich Ihrer Ansicht nach die allgemeine Wirtschaftslage in Deutschland in den kommenden 12 Monaten entwickeln?

Sie wird ...

- sich wesentlich verbessern

- sich etwas verbessern

- in etwa gleichbleiben

- sich etwas verschlechtern

- sich wesentlich verschlechtern

- weiss nicht

Question 7 Wie ist die derzeitige finanzielle Lage Ihres Haushaltes?

- wir sparen viel

- wir sparen ein wenig

- wir kommen mit unseren finanziellen Mitteln so gerade aus

- wir greifen etwas unsere Ersparnisse an

- wir verschulden uns

- weiss nicht

Question 8 Glauben Sie, dass es in Anbetracht der allgemeinen Wirtschaftslage derzeit guenstig ist, groessere Anschaffungen (Moebel, elektrische/elektronische Geraete usw.) zu taetigen? 
- ja, jetzt der Augenblick ist guenstig

- der Augenblick ist weder besonders guenstig noch besonders unguenstig

- nein, der Augenblick ist nicht guenstig

- weiss nicht

Question 10 Wie wird sich Ihrer Ansicht nach die Zahl der Arbeitslosen in Deutschland in den kommenden 12 Monaten entwickeln?

Die Zahl wird ...

- stark steigen

- leicht steigen

- in etwa gleich bleiben

- leicht zurueckgehen

- stark zurueckgehen

- weiss nicht

Question 11 Wollen Sie in den kommenden 12 Monaten fuer groessere Anschaffungen (Moebel, elektrische /elektronische Geraete usw.) mehr oder weniger ausgeben als in den letzten 12 Monaten?

Ich werde ...

- wesentlich mehr ausgeben

- etwas mehr ausgeben

- in etwa gleich viel ausgeben

- etwas weniger ausgeben

- wesentlich weniger ausgeben

- weiss nicht

Question 12 Wie wahrscheinlich ist es, dass Sie in den kommenden 12 Monaten Geld sparen werden?

- sehr wahrscheinlich

- recht wahrscheinlich

- unwahrscheinlich

- sehr unwahrscheinlich

- weiss nicht

Question 13 Glauben Sie, dass es in Anbetracht der allgemeinen Wirtschaftslage derzeit ratsam ist, zu sparen?

- ja, auf alle Faelle

- wahrscheinlich ja

- eher nicht

- auf keinen Fall

- weiss nicht

Question 1 How did you perceive the general economic situation in Germany over the last 12 months?

It ...

- improved substantially 
- improved somewhat

- remained about the same

- worsened somewhat

- worsened substantially

- don't know

Question 2 What is your perception on how consumer prices evolved during the last 12 months?

They ...

- increased substantially

- increased somewhat

- increased slightly

- remained about the same

- decreased

- don't know

Question 3 How will consumer prices evolve during the next 12 months compared to the previous 12 months?

They will ...

- increase more

- increase the same

- increase less

- stay the same

- decrease

- don’t know

Question 4 How did the financial situation of your household evolve during the past 12 months?

It ...

- improved substantially

- improved somewhat

- remained about the same

- worsened somewhat

- worsened substantially

- don't know

Question 5 How will the financial situation of your household evolve during the next 12 months?

It will ...

- improve substantially

- improve somewhat

- remain the same

- worsen slightly

- worsen substantially

- don't know 
Question 6 How will the general economic situation in Germany evolve during the next 12 months?

It will ...

- improve substantially

- improve slightly

- remain the same

- worsen slightly

- worsen substantially

- don't know

Question 7 What is the current financial situation of your household?

- we save a lot

- we save a bit

- we just manage to live from our financial inflows and don't save

- we have to de-save

- we become indebted

- don’t know

Question 8 Given the current economic situation, do you think it's a good time to buy larger items such as furniture, electronic items etc?

- yes, it's a good time

- the time is neither good nor bad

- no, it's a bad time

- don't know

Question 10 What is your expectation regarding the number of unemployed people in Germany in the next 12 months?

It will ...

- increase substantially

- increase somewhat

- remain the same

- decrease somewhat

- decrease a lot

- don't know

Question 11 Do you plan to spend more money during the next 12 months on larger items such as furniture, electronics, etc compared to the previous 12 months?

I will ...

- spend substantially more

- spend somewhat more

- spend about the same

- spend somewhat less

- spend substantially less

- don’t know 
Question 12 How likely is it that you will save money during the next 12 months?

- very likely

- quite likely

- unlikely

- very unlikely

- don't know

Question 13 Given the current economic situation, do you think it's a good time to save right now?

- yes, it's a good time

- probably yes

- not really

- not at all

- don't know 


\section{B. France}

Question 1 A votre avis, au cours des douze derniers mois, la situation économique générale de la France...

- s'est nettement améliorée

- s'est un peu améliorée

- est restée stationnaire

- s'est un peu dégradée

- s'est nettement dégradée

- ne sait pas

Question 2 A votre avis, au cours des douze prochains mois, la situation économique générale de la France...

- va nettement s'améliorer

- va un peu s'améliorer

- va rester stationnaire

- va un peu se dégrader

- va nettement se dégrader

- ne sait pas

Question 3 Pensez-vous que, dans les douze prochains mois, le nombre de chômeurs va ...

- fortement augmenter

- un peu augmenter

- rester stationnaire

- un peu diminuer

- fortement diminue

- ne sait pas

Question 4 Trouvez-vous que, au cours des douze derniers mois, les prix ont ...

- fortement augmenté

- moyennement augmenté

- un peu augmenté

- stagné

- diminué

- ne sait pas

Question 5 Par rapport aux douze derniers mois, quelle sera $\tilde{A}$ votre avis l'évolution des prix au cours des douze prochains mois?

- elle va être plus rapide

- elle va se poursuivre au même rythme

- elle va être moins rapide

- les prix vont rester stationnaires

- les prix vont diminuer

- ne sait pas

Question 6 Dans la situation économique actuelle, pensez-vous que les gens aient intérêt à faire des achats importants? (meubles, machines à laver, matériels électroniques ou informatiques ...) 
- oui, le moment est plutôt favorable

- le moment n'est ni favorable ni défavorable ...

- non, le moment est plut $\tilde{A}^{\prime} t$ défavorable

- ne sait pas

Question 7 Dans la situation économique actuelle, pensez-vous que ce soit le bon moment pour épargner?

- oui, certainement

- oui, peut-ètre

- non, probablement pas

- non, certainement pas

- ne sait pas

Question 8 A votre avis, au cours des douze derniers mois, le niveau de vie en France, dans l'ensemble s'est ...

- nettement amélioré

- un peu amélioré

- restée stationnaire

- un peu dégradé

- nettement dégradé

- ne sait pas

Question 9 A votre avis, au cours des douze prochains mois, le niveau de vie en France, dans l'ensemble va ...

- nettement s'améliorer

- s'améliorer un peu

- rester stationnaire

- se dégrader un peu

- nettement se dégrader

- ne sait pas

Question 10 Laquelle des affirmations suivantes vous semble décrire le mieux la situation financière actuelle de votre foyer?

- vous arrivez à mettre pas mal d'argent de còté

- vous arrivez à mettre un peu d'argent de còté

- vous bouclez juste votre budget

- vous tirez un peu sur vos réserves

- vous ètes en train de vous endetter

- ne sait pas

Question 11 Au cours des douze derniers mois, la situation financière de votre foyer s'est ...

- nettement améliorée

- un peu améliorée

- restée stationnaire

- un peu dégradée

- un peu dégradée

- ne sait pas 
Question 12 Pensez-vous que, au cours des douze prochains mois, la situation financière de votre Foyer va ...

- nettement s'améliorer

- un peu s'améliorer

- rester stationnaire

- un peu se dégrader

- nettement se dégrader

- ne sait pas

Question 13 Pensez-vous réussir à mettre de l'argent de côté au cours des douze prochains mois?

- oui, certainement

- oui, peut-être

- non, probablement pas

- non, certainement pas

- ne sait pas

Question 14 Au cours des douze prochains mois, par rapport aux douze mois passés, avezvous l'intention de dépenser, pour effectuer des achats importants ...

- beaucoup plus

- un peu plus

- autant

- un peu moins

- beaucoup moins

- ne sait pas 


\section{Sweden}

Question 1 Hur ar ditt hushalls ekonomiska situation for narvarande jamfort med for 12 manader sedan? Ar den ...

- Mycket battre

- Nagot battre

- Ungefar lika

- Nagot samre

- Mycket samre

- Vet inte

Question 2 Hur tror du att ditt hushalls ekonomiska situation ar om 12 manader? Ar den $\cdots$

- Mycket battre

- Nagot battre

- Ungefar lika

- Nagot samre

- Mycket samre

- Vet inte

Question 3 Hur tycker du att den ekonomiska situationen ar $i$ Sverige for narvarande jamfort med for 12 manader sedan? Ar den ...

- Mycket battre

- Nagot battre

- Ungefar lika

- Nagot samre

- Mycket samre

- Vet inte

Question 4 Hur tror du att den ekonomiska situationen ar i Sverige om 12 manader? Ar den...

- Mycket battre

- Nagot battre

- Ungefar lika

- Nagot samre

- Mycket samre

- Vet inte

Question 5 Jamfort med for 12 manader sedan, tycker du att priserna $i$ allmanhet for narvarande ar...

- Mycket hogre

- Ganska mycket hogre

- Nagot hogre

- Ungefar desamma

- Lagre

- Vet inte

Question 6 Om du jamfor med dagens situation, tror du att priserna $i$ allmanhet om 12 manader kommer att ... 
- Stiga snabbare

- Stiga i samma takt

- Stiga langsammare

- Vara i stort sett oforandrade

- Sjunka nagot

- Vet inte

Question 7 Hur tror du att arbetslosheten kommer att utvecklas under de narmaste 12 manaderna? Kommer den att ...

- Oka mycket

- Oka nagot

- Vara ungefar som nu

- Minska nagot

- Minska mycket

- Vet inte

Question 8 Har risken for att Du sjalv ska bli arbetslos under de senaste 12 manaderna ...?

- Oka mycket

- Oka nagot

- Vara ungefar som nu

- Minska nagot

- Minska mycket

- Vet inte

Question 9 Tycker du att det $i$ dagslaget ar fordelaktigt for folk $i$ allmanhet att gora stora inkop, som exempelvis mabler, tvattmaskiner, TV osv.?

- Ja, det ar ratt tidpunkt

- Varken ratt eller fel tidpunkt

- Nej, det ar fel tidpunkt, inkapet bar ske senare

- Vet inte

Question 10 Hur mycket pengar tror du att ditt hushall kommer att anvanda till inkop av sadana kapitalvaror under de narmaste 12 manaderna jamfort med de senaste 12 manaderna? Blir det ...

- Mycket mer

- Nagot mer

- Ungefar lika mycket

- Nagot mindre

- Mycket mindre

- Vet inte

Question 11 Mot bakgrund av det allmanna ekonomiska laget, hur tycker du att det ar att spara for narvarande? Som sparande raknas aven minskning av eventuella lan. Ar det...

- Mycket fordelaktigt

- Ganska fordelaktigt

- Varken fordelaktigt eller ofordelaktigt

- Ganska ofordelaktigt 
- Mycket ofordelaktigt

- Vet inte

Question 12 Hur troligt ar det att Ditt hushall kommer att kunna spara nagot under de narmaste 12 manaderna? Som sparande raknas aven minskning av eventuella lan. Ar det ...?

- Mycket troligt

- Ganska troligt

- Inte sarskilt troligt

- Inte alls troligt

- Vet inte

Question 13 Vilket av faljande pastaenden beskriver bast ditt hushalls nuvarande ekonomiska situation?

- Vi skuldsatter oss och/ eller utnyttjar sparade medel i stor utstrackning

- Vi skuldsatter oss och/ eller utnyttjar sparade medel

- Vi gar ungefar jamnt upp

- Vi sparar nagot

- Vi sparar mycket

- Vet inte 


\section{United Kingdom}

Question 1 How has the financial situation of your household changed over the last 12 months?

It has ..

- Got a lot better

- Got a little better

- Stayed the same

- Got a little worse

- Got a lot worse

- Don’t Know

Question 2 How do you expect the financial position of your household to change over the next 12 months?

It will ...

- Get a lot better

- Get a little better

- Stay the same

- Get a little worse

- Get a lot worse

- Don't Know

Question 3 How do you think the general economic situation in this country has changed over the past 12 months?

It has ...

- Got a lot better

- Got a little better

- Stayed the same

- Got a little worse

- Got a lot worse

- Don't Know

Question 4 How do you expect the general economic situation in this country to develop over the next 12 months?

It will ...

- Get a lot better

- Get a little better

- Stay the same

- Get a little worse

- Get a lot worse

- Don't Know

Question 5 How do you think consumer prices have developed over the last 12 months?

They have ... 
- Risen a lot

- Risen moderately

- Risen slightly

- Stayed about the same

- Fallen

- Don't Know

Question 6 In comparison with the past 12 months, how do you expect consumer prices will develop in the next 12 months?

They will ...

- Increase more rapidly

- Increase at the same rate

- Increase at a slower rate

- Stay about the same

- Fall

- Don’t Know

Question 7 How do you expect the number of people unemployed in this country will change over the next 12 months?

The number will ...

- Increase sharply

- Increase slightly

- Remain the same

- Fall slightly

- Fall sharply

- Don’t Know

Question 8 In view of the general economic situation, do you think now is the right time for people to make major purchases such as furniture or electrical goods?

- Yes, now is the right time

- It is neither the right time nor the wrong time

- No, it is the wrong time

- Don't Know

Question 9 Compared to the last 12 months, do you expect to spend more or less money on major purchases such as furniture and electrical goods?

I will spend ...

- Much more

- A little more

- About the same

- A little less

- Much less

- Don't Know

Question 10 In view of the general economic situation, do you think that now is? 
- A very good time to save

- A fairly good time to save

- Not a good time to save

- A very bad time to save

- Don't Know

Question 11 Over the next 12 months, how likely will you be to save any money?

- Very likely

- Fairly likely

- Not likely

- Not at all likely

- Don't Know

Question 12 Which of these statements best describes the current financial situation of your household?

- We are saving a lot

- We are saving a little

- We are just managing to make ends meet on our income

- We are having to draw on our savings

- We are running into debt

- Don’t Know 


\section{A.2 Additional Discussion of the Measure of Unconventional Fiscal Policy}

In this section, we describe in detail the narrative records surrounding the 2005 general elections in Germany, and the relationship between willingness to spend and actual spending, inflation expectations and actual inflation, the potential mapping of our findings into the framework of Correia et al. (2013), the marginal effect of inflation expectations on consumption expenditure over time, salience of VAT changes, and the differences between reduced and full VAT rates.

Relevant Narrative about the 2005 German Elections. The Christian Democrats (CDU, center-right) were the only German party in the 2005 electoral campaign advocating an increase in VAT by $2 \%$ starting in January 2006 to lower non-wage labor costs (see CDU (2005), page 14). The Social Democrats (SPD, center-left) strongly opposed an increase in VAT, and instead favored a 3\% increase in income tax for top income earners (see SPD (2005), page 39). The Greens (center-left) and Liberals (center-right) also strongly opposed an increase in VAT. The Liberals, for example, promised to decrease the general tax burden by EUR 19bn.

All parties except the CDU strongly opposed raising VAT, including CDU's preferred coalition partner, the Liberals. The projections of the election outcomes were highly uncertain (see below), as were the fiscal policy measures the new government would have implemented. A VAT increase of $3 \%$ was therefore highly unexpected. Consistently, the opposition parties and the popular press accused the new government between CDU and SPD of electoral fraud after it announced this policy measure in November 2005, and they fiercely criticized the new government. The online appendix contains press clippings commenting on the VAT policy (see section A.5 of the online appendix).

Empirically, households' inflation expectation over the next 12 months did not increase until January 2006, after the new government had announced its plans in November 2005 to increase VAT in 2007, rather than 2006 as the CDU had planned initially which is direct evidence German households did not expect an increase in VAT in 2006, as the CDU proposed. ${ }^{1}$

Neither of the two blocks - CDU and Liberals on the one hand, and SPD and Greens on the other hand-had a majority in polls before the elections. ${ }^{2}$ In the actual election on September

\footnotetext{
${ }^{1}$ If voters had considered the CDU proposal credible, we should already see an increase in inflation expectation during the campaign in the summer of 2005, because the plan was to increase VAT in January 2006.

${ }^{2}$ Eleven days before the elections, the polling institute Infratest Dimap predicted a vote share of $41 \%$ for the CDU, $34 \%$ for the SPD, $8.5 \%$ for the Left, $7 \%$ for the Greens, and $6.5 \%$ for the Liberals. See http://www.infratestdimap.de/en/umfragen-analysen/bundesweit/sonntagsfrage/. All parties explicitly ruled out any coalition with the Left. The media mentioned all other possible combinations, including non-traditional combinations, as possible coalitions, including a "traffic-light" coalition among SPD, Greens, and Liberals and a "Jamaica" coalition among CDU, Liberals, and Greens.
} 
18, 2005, the CDU gained 35.2\% electoral support; the SPD, 34.2\%; the Liberals, $9.8 \%$; the Left, $8.7 \%$; and the Greens, $8.1 \%$. Neither the CDU nor the SPD were able to form a "small" coalition with their preferred coalition partner (Liberals and Greens, respectively). The CDU and SPD therefore agreed to form a "grand" coalition.

The coalition agreed on an overall contractionary fiscal policy (see below), including the $3 \%$ increase in VAT, and the use of one third of the additional tax revenue to decrease non-wage labor costs by two percentage points. The government planned to use two thirds of the VAT increase to consolidate the federal budget to comply with the Maastricht Treaty and hinder an infringement procedure by the European Commission. Table ?? in the online appendix shows the total tax revenue indeed increased in 2007, and Germany no longer violated the EU Stability and Growth Pact.

Concurrent Policy Measures. The new government announced additional policy measures as part of its coalition agreement. The preamble of the official agreement emphasizes the need to reduce Germany's public debt as the major challenge for the new government, and the set of agreed-upon policy measures would be contractionary overall. In addition to the VAT increase and the non-wage labor-costs reduction, the government announced an investment program of $0.25 \%$ of 2005 GDP per year over the following four years. The government planned to finance the majority of the program through budget cuts. Moreover, the government announced an increase in the top marginal income tax rate from $42 \%$ to $45 \%$ for incomes above EUR 250,000 for singles and EUR 500,000 for couples. The Panel of Household Finances of the Deutsche Bundesbank reports for 2014 a $95^{\text {th }}$ percentile of gross income of EUR 113,900, which implies the tax increase only affected a small fraction of households. Lastly, the government planned to increase indirect taxes for retirement from $19.4 \%$ to $19.9 \%$, and it abolished the home-buyer subsidy, which had been guaranteed since 1949, and amounted to EUR 11.4 billion in 2004. ${ }^{3}$ The overall contractionary nature of this set of policies suggests our estimates in section II represent a lower bound of the positive effect of the announcement to increase VAT in 2007 on households' willingness to purchase durables.

Willingness to Spend versus Actual Spending. We are ultimately interested in how inflation expectations transform into actual consumption expenditure. Our survey only reports the willingness to purchase durable goods. Figure A.1 in the online appendix is a scatter plot of the cyclical components of log real durable consumption expenditure and the average propensity to purchase durables. ${ }^{4}$ Real and reported spending on durables are positively related, which is consistent with Bachmann et al. (2015). The correlation is 0.46 .

\footnotetext{
${ }^{3}$ See http://www.kas.de/upload/ACDP/CDU/Koalitionsvertraege/Koalitionsvertrag2005.pdf for details.

${ }^{4}$ We use a Hodrick-Prescott filter with smoothing parameter $\lambda$ of 1,600 to extract the cyclical component.
} 
The reported willingness to purchase has potential advantages compared to measures of actual expenditures elicited with surveys. Spending data in surveys typically contain noise, because survey participants might not recall their actual purchases, or they might overstate their purchases of visible products, such as cars, and understate the consumption of "sin" products, such as tobacco and alcohol (see Hurd and Rohwedder (2012) and Atkinson and Micklewright (1983)).

Empirical Evidence and Relationship with Theory. Correia et al. (2013) formalize the ideas in Shapiro (1991), Feldstein (2002), and Hall (2011) and study unconventional fiscal policy in a New Keynesian model. They show unconventional fiscal policy can fully circumvent the zero-lower-bound constraint on nominal interest rates in a budget-neutral and time-consistent manner. Their benchmark model is a textbook New Keynesian model, in which labor is the only factor of production. This model suggests that an increasing path of consumption taxes generates inflation expectations and negative real interest rates. Lower labor income taxes ensure consumption taxes do not affect the intratemporal margin between leisure and consumption, and hence the real wage. Firms' pricing decisions are independent of the change in consumption taxes, and marginal costs do not change either. Therefore, the production allocation across firms is efficient and the government can offset the distortion coming from monopoly rents with taxes as in the textbook model.

Our natural experiment resembles the proposals in Shapiro (1991), Feldstein (2002), and Hall (2011), but deviates from the setting in Correia et al. (2013) in a few dimensions. First, the German government used 2 percentage points of the $3 \%$ increase in VAT to consolidate the federal budget, and 1 percentage point to lower indirect labor taxes by $2 \%{ }^{5}$ Empirically, we do not find any effect on labor force participation or unit labor costs. ${ }^{6}$ Moreover, we find similar marginal effects of inflation expectations on the propensity to purchase durables for full-time, part-time, and unemployed survey participants. In addition, Nakamura, Steinsson, Sun, and Villar (2016) question whether producer price dispersion has real economic costs.

Second, we only observe attitudes towards purchases of durable goods. In a model with both durable and non-durable consumption, the intertemporal substitution effect of higher future consumption taxes is larger for durable goods (see Barsky et al. (2007) and Barsky et al. (2016)). ${ }^{7}$

\footnotetext{
${ }^{5}$ Efficiency gains in the unemployment insurance system financed the second percentage-point decrease in indirect labor taxes.

${ }^{6}$ Data from the OECD show unit labor costs decreased in Germany during 2006 and 2007 in absolute terms and relative to France, Sweden, and the UK (see: http://stats.oecd.org/Index.aspx?QueryName=426). Labor force participation, instead, barely changed from $58.4 \%$ in 2005 to $59.1 \%$ in 2007 (see: http://data.worldbank.org/indicator/SL.TLF.CACT.ZS?locations=DE).

${ }^{7}$ Shapiro (1991) already emphasizes the effect of unconventional fiscal policy should mainly operate through expenditure on durable goods. Storability of durable goods can lead to an increase in durable expenditure due to a future increases in VAT even if the IES is small through an arbitrage effect.
} 
A potential concern for policymakers aiming to stimulate overall consumption is that households might substitute intratemporally from non-durable to durable consumption, because the VAT change did affect nondurable goods less than durable goods (see discussion below). We do not observe households' attitudes towards purchases of non-durable goods. To address this concern directly, we show realized non-durable consumption growth increased during 2006. German households also lowered their savings attitudes during 2006 in absolute terms and relative to matched foreign households, supporting the conclusion that households increased overall consumption (see Table 5).

Third, Correia et al. (2013) study unconventional fiscal policies during a liquidity trap, whereas we study the effect for a single country in a currency union. To predict higher consumption, the consumption Euler equation requires only that nominal interest rates not increase sufficiently to offset the increase in inflation expectations rather than being in a liquidity trap. The ECB explicitly excluded an increase in nominal interest rates to counteract the announcement of a higher VAT in Germany, because it believed the increase in consumer price inflation would be temporary and limited to Germany. The then-president of the German Bundesbank excluded an increase in nominal rates to offset inflationary pressure: "We know what the effects of the VAT increase are; as is the case for oil prices, we do not consider one-off effects" (see Weber (2006); see also section A.3 in the online appendix). Nominal interest rates for consumption loans also barely changed and were $6.7 \%$ in January 2006 and $6.4 \%$ in December 2007. Moreover, in our difference-in-differences estimation in section II, we compare the behavior of German households to matched French households that face the same nominal interest rates as German households.

Last, we study the pre-announced increase in VAT rather than consumption taxes. Correia et al. (2013) already highlight both VAT and consumption taxes should have similar implications because of "the extensive evidence of very high pass-through of consumption taxes even in the cases in which the usual practice is to quote after-tax prices, as is the case for the value-added tax in Europe." This point is consistent with the ex-ante expectations for the specific case of the VAT increase in Germany and the actual ex-post result. The Association of Consumer \& Home Electronics expected the increase in VAT would be fully passed through to consumers (see Stehle (2006)). Ex-post, the German statistical office shows some categories immediately and fully adjusted prices, such as tobacco and services, whereas other categories adjusted prices with a delay, such as electronics and furniture. By early 2008, all categories underlying the German CPI had fully adjusted their prices by the theoretical amount. ${ }^{8}$

\footnotetext{
${ }^{8}$ See https://www.destatis.de/DE/Publikationen/WirtschaftStatistik/Preise/MwSterhoehungJan2007.pdf.
} 
Farhi et al. (2014) show an increase in VAT coupled with a decrease in payroll subsidy can, under certain conditions, replicate an exchange-rate devaluation even within a currency union. Theoretically, this fiscal devaluation makes goods in Germany cheaper than French goods and results in an increase in the demand for goods produced in Germany by both French and German households. Crucially, the fiscal devaluation should barely affect the overall consumption decision of French households, and hence the spending attitudes of French households represent a plausible counterfactual for the spending attitudes of German households in our setting.

Salience of VAT Changes. Pre-announced VAT increases are a salient way to generate future consumer price inflation and induce current spending compared to conventional and unconventional monetary policy or future government purchases. Menz and Poppitz (2013) study the media coverage of inflation in Germany during the time period of our natural experiment and document a surge in coverage of inflation.

Reduced and Full VAT. All services and products in Germany are subject to a valueadded tax that is part of the European VAT system. The general tax rate was $16 \%$ until December 2006, and increased to $19 \%$ in 2007. A reduced rate of $7 \%$ applies to many convenience goods, such as food, books, or flowers. The reduced rate has been unchanged since 1983. Rent, services for non-profit organizations, and medical expenses are not subject to VAT. Virtually all durable goods are subject to the full VAT, whereas only $59 \%$ of non-durables are subject to a VAT rate of $19 \%$. 


\section{A.3 ECB View on German VAT Increase}

In this section, we report the answer of the former president of the ECB, Jean-Claude Trichet, during a Q\&A after the introductory remarks following the council meeting on October 5 2006. The full transcript can be found here: https://www.ecb.europa.eu/press/pressconf/2006/html/is061005.en.html

Question: [...] Seeing how you have to think ahead as good central bankers, I wondered if you could tell us what your working hypothesis is regarding the effects on price stability and on growth of the value added tax increase that is coming in a large European country on 1 January?

Trichet: [...] As regards your second question I will not enter into our baseline scenario. If the baseline scenario was not confirmed, whether it would be upward or downward, we would draw the appropriate consequences. We have a compass and we have a needle in our compass: it is price stability, the delivery of price stability in the medium-term and the credibility of the delivery of price stability. It is because we are credible in the delivery of price stability that our inflationary expectations are anchored in line with our definition of price stability. This solid anchoring is essential, as I have said, for sustainable growth and job creation in the medium and long-term. As regards the profile of HICP due to the VAT increase in one big economy in the euro area, clearly there we have, I would say, a mainstream analysis which is suggesting that we will have a hump in HICP, starting in January 2007 it is extraordinarily likely, arithmetically speaking, and there is also a probability of having more consumption in the last quarter of this year, and less consumption in the first quarter of next year. That's also clearly suggested by the situation. As you know, there are several schools of thought around the mainstream analysis, and we will see exactly what happens. My sentiment-and I am communicating the overall sentiment of the Governing Council-is that after a relatively short period of volatility we will go back to more normal behaviour. We should not pay too much attention to the short-term volatility that would be induced by this phenomenon. In any case we think in the Governing Council that we must extract information from all sources we have as far as data, facts, figures are concerned, and extract from that an assessment on the trend. You remember we had a very poor quarter in the last quarter last year. It was, until the recent revision upward, only $0.3 \%$, it was disappointing obviously but we said it doesn't put into question our understanding of what is the trend growth. And the results of the first and second quarters of this year confirmed that our assessment of the situation was fully justified. 


\section{A.4 Data}

When conducting the survey, GfK also collects a rich set of demographics. We enlist the variables below, and report the possible values the variables obtained in the sample in parentheses.

Sex (male, female), age (continuous), household size (1, 2, 3, 4, 5 and more), city size $(0 \leqslant$ size $\leqslant 1,999,2,000 \leqslant$ size $\leqslant 2,999,3,000 \leqslant$ size $\leqslant 4,999,5,000 \leqslant$ size $\leqslant 9,999, \quad 10,000 \leqslant$ size $\leqslant 19,999$, $20,000 \leqslant$ size $\leqslant 49,999, \quad 50,000 \leqslant$ size $\leqslant 99,999, \quad 100,000 \leqslant$ size $\leqslant 199,999, \quad 200,000 \leqslant$ size $\leqslant 499,999$, $500,000 \leqslant$ size), marital status (single, couple, married, widowed, divorced, separated), children at home (yes, no), number of children (1, 2, 3, 4 and more), homeownership (house owner, apartment owner, renter), household head (yes, no), education (Hauptschule, Realschule, Gymnasium, University), employment (full-time, part-time, not employed), state (Schleswig-Holstein, Hamburg, Bremen, Berlin(West), Niedersachen, Nordrhein-Westfalen, Hessen, Rheinland-Pfalz, Saarland, Baden-Wuerttemberg, Bayern, Mecklenburg-Vorpommern, Sachsen-Anhalt, Brandenburg, Thueringen, Sachsen, Berlin(Ost)), monthly net income (inc) $\quad$ inc $\leqslant 500, \quad 500<$ inc $\leqslant 750, \quad 750<$ inc $\leqslant 1,000, \quad 1,000<$ inc $\leqslant 1,2500, \quad 1,2500<$ inc $\leqslant 1,500$, $1,500<$ inc $\leqslant 2,000, \quad 2,000<$ inc $\leqslant 2,500, \quad 2,500<$ inc $\leqslant 3,000, \quad 3,000<$ inc $\leqslant 3,500, \quad 3,500<$ inc $\leqslant 4,000$, $4,000<$ inc), job (farmer, liberal profession, self-employed, civil servant, white-collar worker, blue-collar worker, student, trainee, draftee, housewife, retiree, unemployed).

Data on the consumer price index, the unemployment rate, real durable consumption expenditure, real GDP, and industrial production are from the German Statistical Office (DeStatis); Data on the European and German uncertainty index are from Baker et al. (2016); Data on DAX and Volatility DAX are from the Deutsche Boerse; and oil price data are from Bloomberg.

We obtain the harmonized consumer price indexes (CPI) from the Statistical Data Warehouse at the European Central Bank. The data ID for the harmonized overall CPI is ICP.M.DE.N.000000.4.INX; for the all items CPI excluding food and energy it is ICP.M.DE.N.XEF000.4.INX; for the major durables CPI it is ICP.M.DE.N.0921_2.4.INX; and for the non-durable households goods CPI it is ICP.M.DE.N.056100.4.INX.

We obtain data for bank interest rates for loans to households in Germany for consumption from the Statistical Data Warehouse at the European Central Bank. The data ID is MIR.M.DE.B.A2B.A.R.A.2250.EUR.N. The rate is the annualized agreed rate, narrowly defined effective rate, for new loans for consumption excluding revolving loans and overdrafts, convenience and extended credit card debt.

Inflation expectations data for European Union member countries are from the European Commission Directorate on Economic and Financial Affairs. 


\section{A.5 Press Clippings}

We briefly cite a few media quotes following the announcement of the newly-elected administration in 2005 to increase VAT by $3 \%$.

"Mehrwertsteuer ist glatter Betrug an den Waehler." Gruenen-Vorsitzende Claudia Roth haelt den Koalitionsvertrag fuer unsozial

"VAT is electoral fraud." Green party leader Claudia Roth calls coalition agreement antisocial Berliner Morgenpost, 11/21/2005

Opposition kritisiert "Wahlbetrug." Vor allem hoehere Mehrwertsteuer stoesst auf Protest Opposition criticizes "electoral fraud." Especially higher VAT fiercely criticized

Frankfurter Rundschau, 11/14/2005

Opposition spricht von Wahlbetrug.

Opposition stresses "electoral fraud."

Die Welt, 11/13/2005

Die dreissten Steuerluegen.

Unapologetic tax lies.

Berliner Morgenpost, 5/19/2006

Westerwelle geisselt Steuererhoehungen.

Westerwelle criticizes tax hike.

Sueddeutsche Zeitung, 5/15/2006

Warum luegen Politiker?

Why do politician lie?

Welt am Sonntag, 5/14/2006 


\section{Figure A.1: Cyclical Readiness to Spend on Durables and Real Durable Consumption}

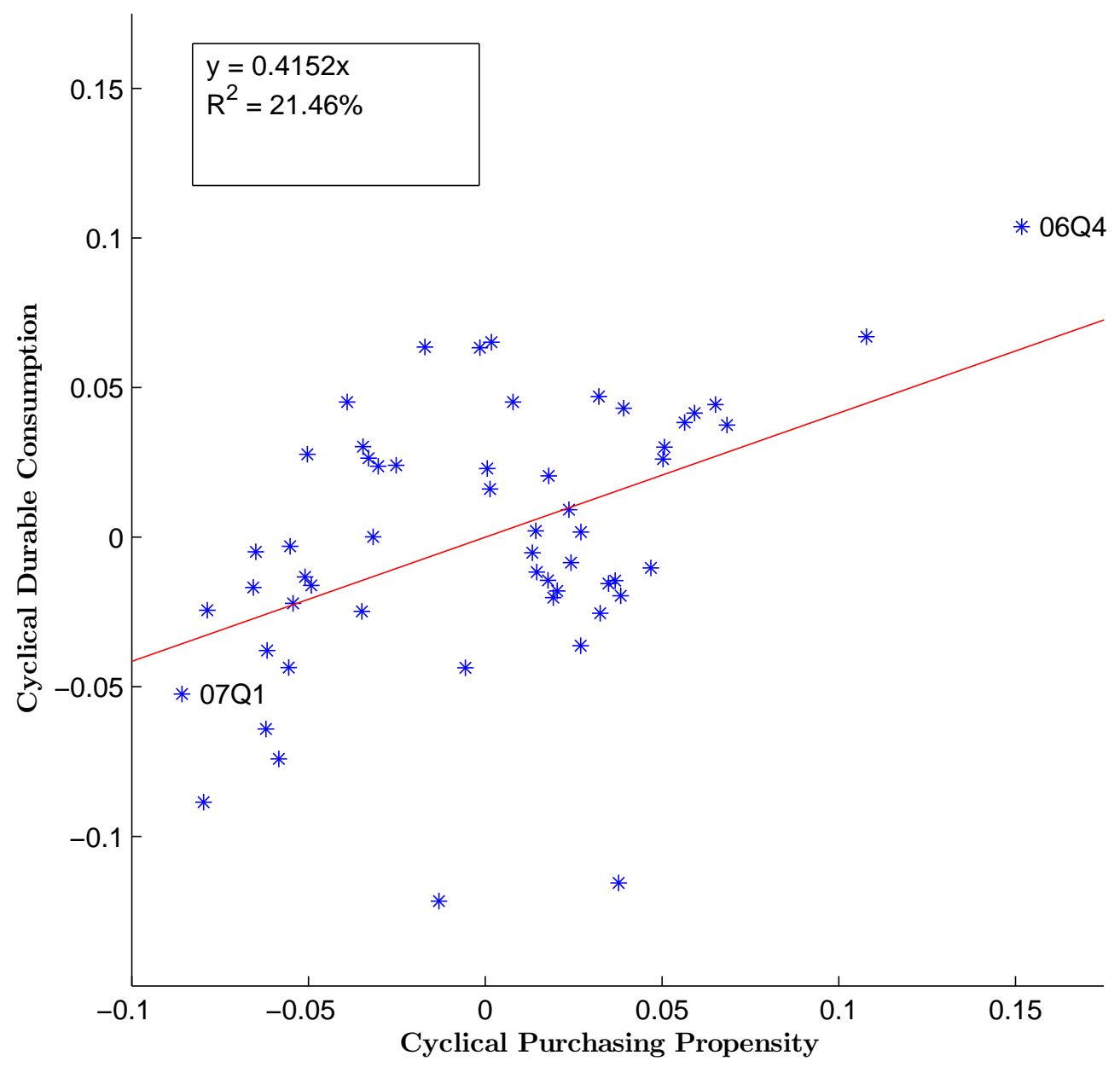

This figure is a scatter plot of the cyclical components of the average monthly readiness to purchase durables over time and of the natural logarithm of the real durable consumption at the quarterly frequency. We use a Hodrick-Prescott filter with smoothing parameter $\lambda=1,600$ to estimate the cyclical component. We use the confidential micro data underlying the GfK Consumer Climate MAXX survey to construct the readiness to purchase durables index. GfK asks a representative sample of 2,000 households whether it is a good time to purchase durables given the current economic conditions. Higher values correspond to better times. We use the end of quarter value to get a quarterly time series. The sample period is fist quarter 2000 to fourth quarter 2013 for a total of 14 years. 
Figure A.2: Inflation Expectations and Lagged Realized Durable Inflation Rate

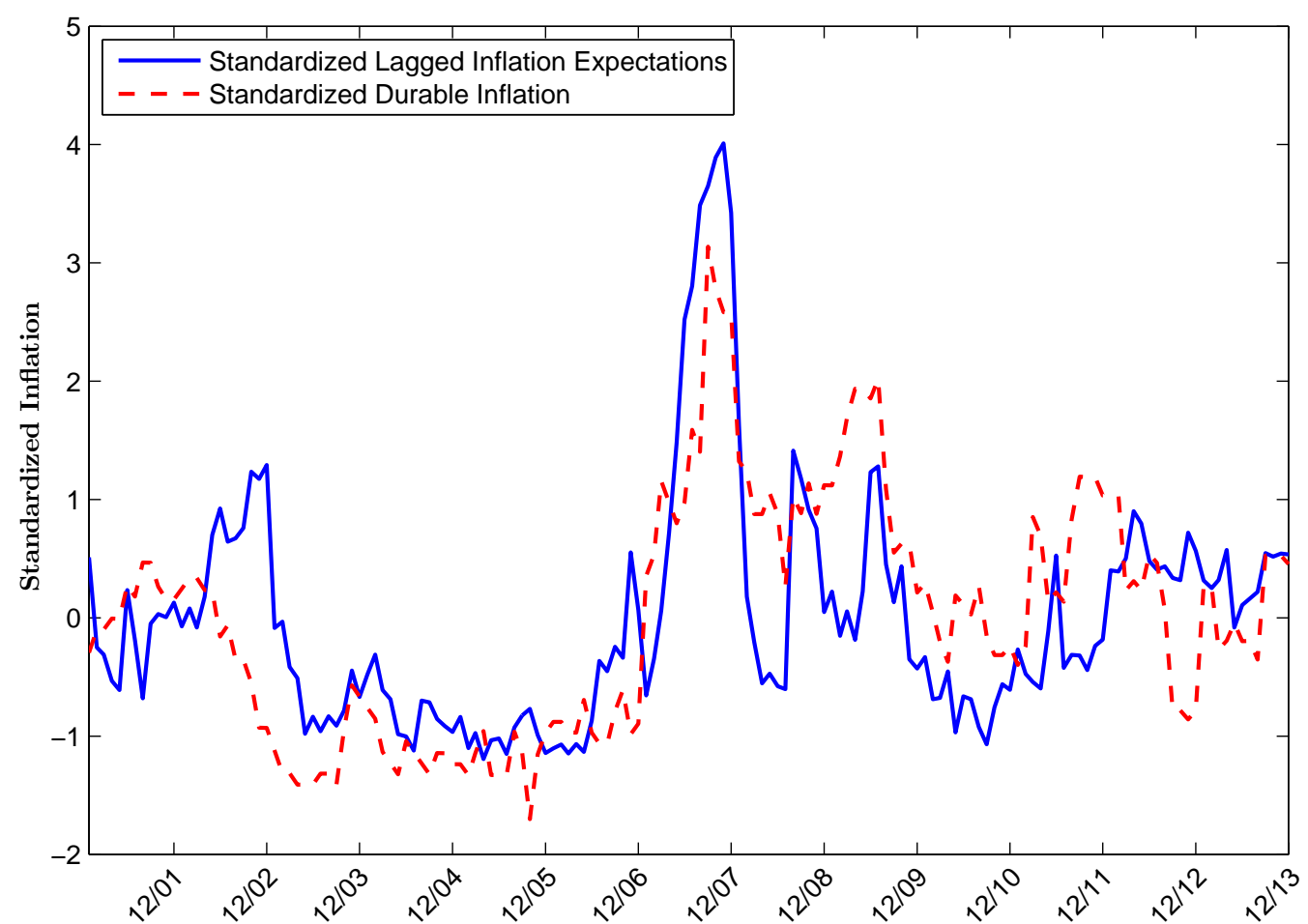

This figure plots the monthly time series of the one-year standardized average monthly inflation expectation and the lagged harmonized major durables consumer price inflation rate in percent at an annual rate. We use the confidential micro data underlying the GfK Consumer Climate MAXX survey to construct inflation expectations. GfK asks a representative sample of 2,000 households how consumer prices will evolve in the next 12 months compared to the previous 12 months. We create a dummy variable which equals 1 when a household expects inflation to increase. The sample period is January 2000 to December 2013 for a total of 14 years. 
Figure A.3: Time Series of CPI Inflation rate
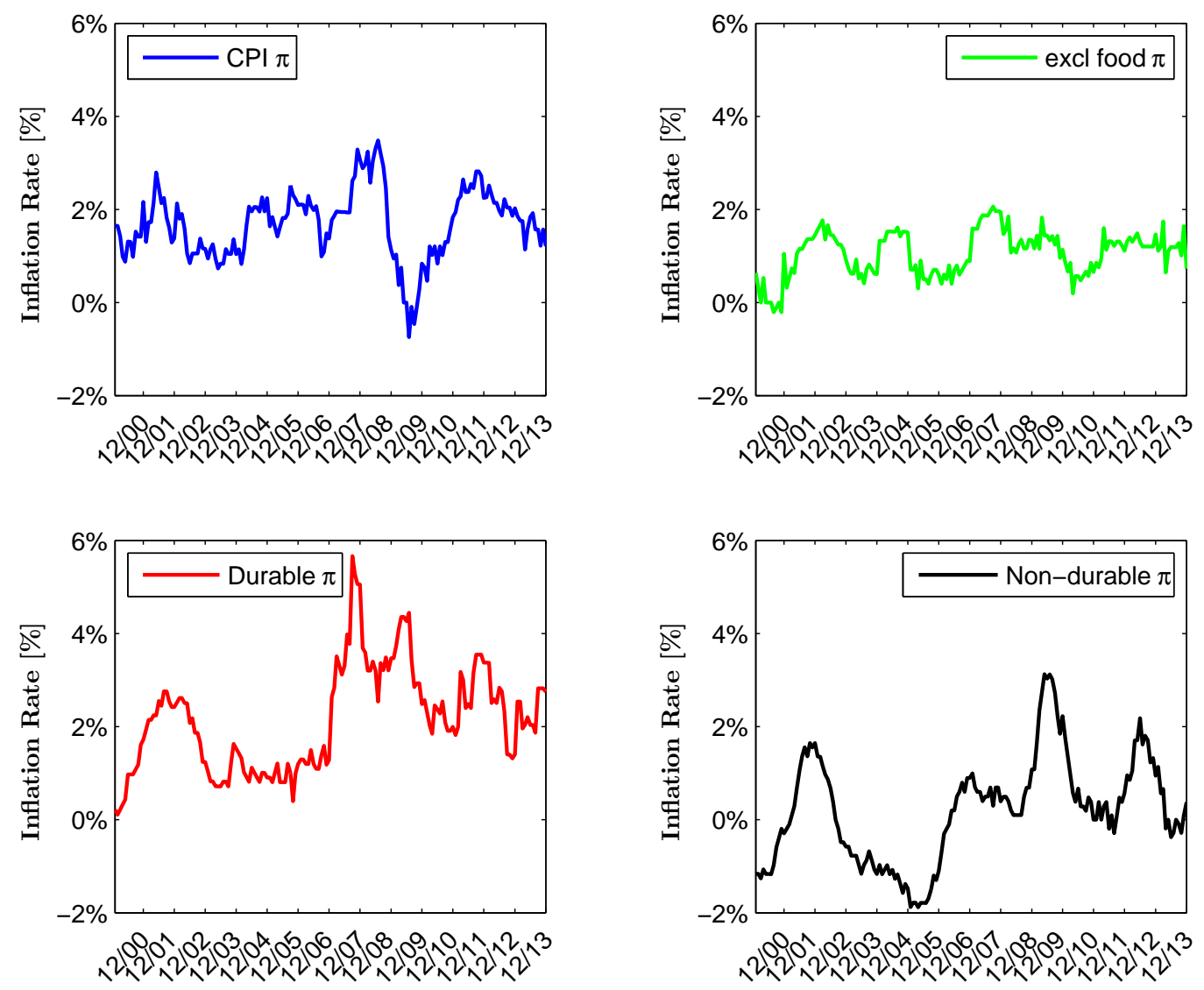

This figure plots the monthly time series of the German consumer price (CPI) inflation rate $\pi$ in percent at an annual rate. The top left panel plots the harmonized overall consumer price inflation rate. The top right panel plots the all items CPI excluding food and energy. The bottom left panel plots major durables CPI. The bottom right panel plots the non-durable households goods CPI. The sample period is January 2000 to December 2013 for a total of fourteen years. 